Most of the improvements are likely to lead to an increase in capital cost. Some may involve slight increase in maintenance costs. if these choices are not consciously considered the lessons from the Inangahua Earthquake would have been wasted.

Re: Mr A.L. Andrews Article in Bulletin of July, 1968

I was interested in this article because:-

(a)

It had direct reference to Fleming"s portal and cantilever methods.

(b) The paper provided a good instance of the difficulties axising from assumptions and approximations in aseismic design.

As regards Fleming and his simplified methods; he developed them about 50 years ago. This was not long after the monumental studies of building frames by Professor Wilson of Illinois. These covered both gravity and lateral loading and were on a slope - deflection basis. Fleming was acelebrated engineer of his day whose work in practice was highly regarded. His views were often sought and his recommendations quoted by reliable authorities. Then, about 40 years ago, came the notable studies of deflected structures by Professor Hardy Cross, whose work particularly as to mement and shear distribution has been applied and extended for more than a generation. Yet in spite of all this no practicable analytical methods seem to be available to give anything more than a very dubious estimate of deflections due to seismic effects on multi-storey buildings. There are far too many imponderables, both within the structure and externally. But we have to try to cope with these as best we can - hence many approximations and assumptions. It is here that the paper is of particular interest; it demonstrates, by one fundamental instance, the need for continuing appraisal of the effects of any initial assumption or approximations.

As to structural approximations in general I have found "statically Indeterminate Structures" by Benjamin of Stanford (1959) particularly good. Although I do not care for his treatment of shear walls that have openings In them, the letterpress of the book as a whole show's a firm grasp of the relationships between theory and reality。

Reverting once more to estimating deflections in buildings - I think that for anything in which we could have much confidence we are forced right back to more full scale local test data. In other words we need sufficient instrumental data from modern local structures plus the relevant seismological records. Such date can't be got or intexpreted easily or cheaply but they are urgently needed. There is no worthwhile substitute: the complexities of transient response and damping, apart from many other factors, determine this. Who can or will, or whose business is it, to get and handle the information?

P.S. Structural Engineers Association of California a few years back made some suggestions about allowances for storey drift floor to floor and when to allow for same. But in the end recommendations were left merely as guidance and nothing, unless quite recently, has been made mandatory. 


\title{
EARTHQUAKE DAMAGE TO THREE RAILWAY BRIDGES 1968 INANGAHAU EARTHQUAKE
}

\author{
4. J.P. Hollings, B.E., D.I.C. M.I.C.E. M.N.Z.I.E. \\ 1. A. N. Fraser, B.E. (Hons.)
}

\subsection{Synopsis}

This report describes in detail the measured deformations and damage suffered. by two combined road-rail and one rail bridge in the 24.5 .68 Inangahua earthquake. The measured deformations are plotted in diagram form for each bridge and photographs of all typical damage are presented. No interpretive or analytical material has been included.

\subsection{Introduction}

At 5.24 a.m. on 24.5 .68 N.Z.S.T. a magnitude 7.0 earthquake of focal depth 12 kilometres originated some 10 miles north of Inangahua township in Westland, N.Z.

The earthquake resulted in three deaths and injuries to 14 people. There were major landslides in the gorge of the Buller River with slumping, fissuring and sand fountaining. At Inangahua intensities of MMX have been estimated, while preliminary analyses of horizontal scratch plate accelerographs (on alluvium) give readings of $0.35 \mathrm{~g}$. at Reefton, $0.30 \mathrm{~g}$. at. Greymouth and $0.25 \mathrm{~g}$. at Westport. Distant 30 miles, 67 miles and 21 miles respectively from the epicentre.

This report describes damage to three bridges which were grouped in the area close to Inangahua (Refer Figure 1B) and which were almost the only major structures seriously damaged in the area. Bridges along the railway on the Reefton approach to Inangahua were mainly timber truss spans on timber piles and were undamaged and bridges on the Westport approach to Inangahua were mainly monolithic reinforced concrete structures and were also generally undamaged. (But see two bridges noted on Figure 1B).

For each of the three bridges this report is restricted to a factual statement of the damage incurred and the permanent displacements measured. No interpretation or analysis is attempted.

The Landing Bridge was measured on 27th, 28th and 29th May and the two other bridges were measured in the period 7 th to 11 th June. Urgent repair work was under way on the bridges during the measuring as is evident in some of the photographs.

\footnotetext{
+ J.P. Hollings - Partner in Beca Carter Hollings \& Ferner, Consulting Engineers

+ I.A.N. Fraser - Assistant Engineer in Beca Carter Hollings \& Ferner, Consulting Engineers
} 


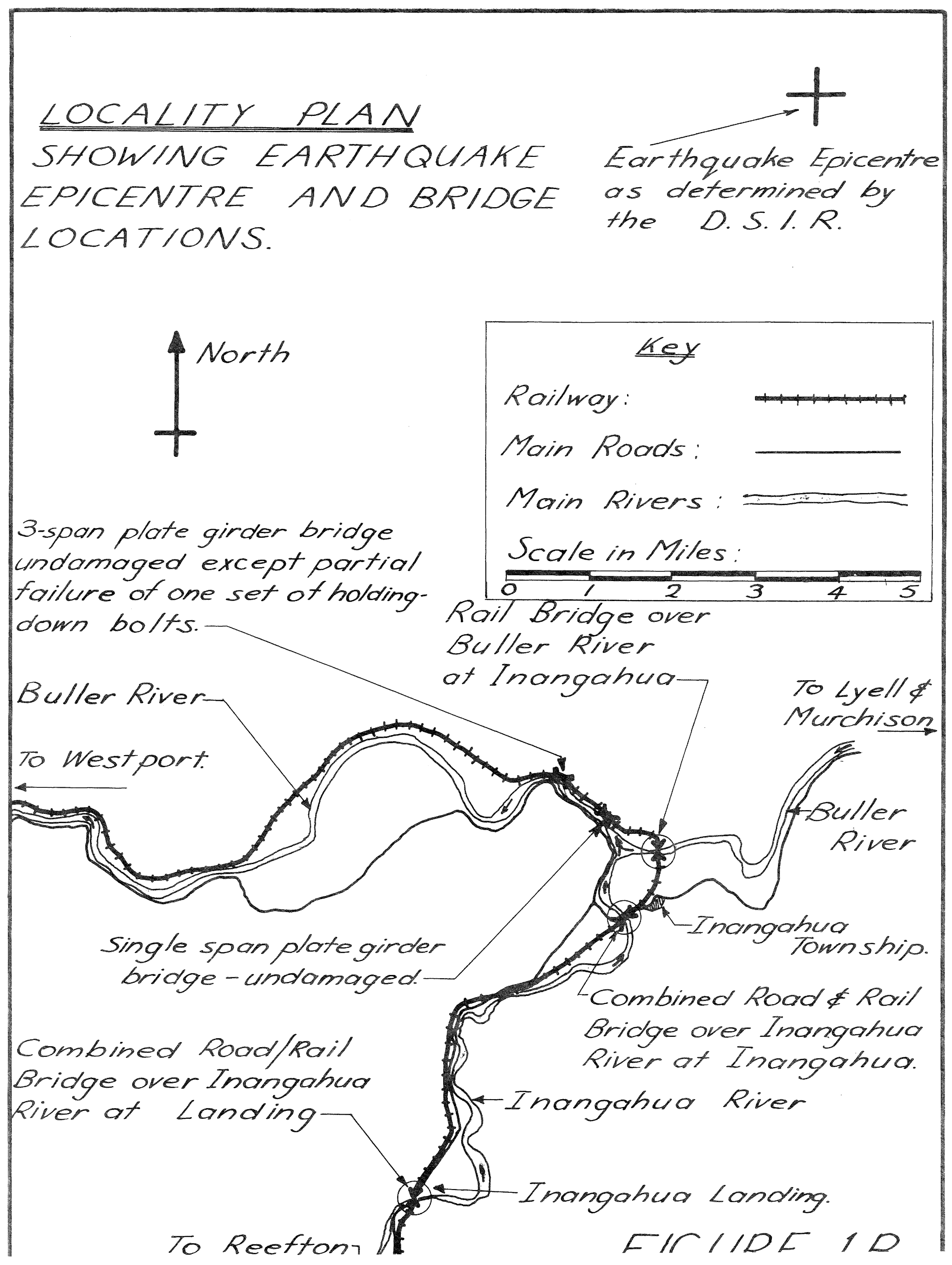




\subsection{Report on earthquake damage to the landing bridge on 24.5.68:}

\subsection{General Description of the Bridge Structure:}

This bridge, which is a combined single lane road and rail bridge, was constructed prior to 1910 for the Midland Railway Company to the design of Robert Wilson, M.I.C.E., the then Chief Engineer.

It is now owned and maintained by the N.Z. Government Railways as a part of the state system.

Copies of the original construction plans are still in existence and Figure $1 \mathrm{~A}$ shows the general arrangement of the bridge as traced from these plans.

The "rock" shown as foundation for Piers 1, 3, 4 and 5 is a mudsandstone of the Miocene epoch. Piers 1 and 5, the abutments and their wing walls are of massive mass concrete construction entirely unreinforced. Piers 2, 3 and 4 are also of mass concrete but rest on cast iron cylinders as shown and are reinforced only by the twin rails provided to increase the flood resistance of the pier.

The bridge trusses have hardwood compression members; the tension verticals are twin mild steel rods; and the bottom chords are twin mild steel flats with rivetted connections. The trusses rest on timber corbels which in turn rest on timber sills and the whole of this assembly is through bolted to each of the concrete piers and abutments. The deck system which supports both roadway and rails consists of timber transoms at each panel point supporting timber road and rail beams which, like the trusses, are corbelled and through bolted to the concrete work.

The bridge was well designed, has been well maintained and was generally in sound physical condition at the time of the earthquake. bridge.

It is not known whether the 1929 Murchison earthquake damaged this

\subsection{Description of the Longitudinal Displacements} suffered by the Bridge during the Earthquake:

The evidence of longitudinal movements of the bridge is presented in Figures 1 and 2 and in the Plumb-line data plotted in Figure 3.1. From these figures together with certain other data which appears in the discussion below the following statements can be made about the longitudinal bridge movements.

1. Both rails (the individual lengths of which are of course fishplated together into continuous members) were forced by the bridge movements to oscillate in a north-south direction as a single unit extending through the bridge and several chains on either side of it. 
2. The amplitude of this movement was at least 4" (Figure 1.6) and the rail system finished. with a permanent displacement of $2 \frac{1}{2} "$ northwards relative to the base rock. (Figure 1.5).

3. Generally the screw spikes attaching the rails to the sleepers had sufficient frictional grip to force the sleepers (and hence a substantial amount of ballast between the sleepers) to follow the track movements.

4. Relative to this moving rail system the bridge deck had an amplitude (north-south movements, $i$.e. parallel to the track) of $3 \frac{1}{2} "$ and a permanent displacement northwards of 1 $\frac{1}{2}$ " (Figure 1.1).

5. Thus Figures 1.1 and 1.5 taken together show that the bridge deck has moved permanently $2 \frac{1}{2}+1 \frac{1}{2}=4 "$ northwards relative to the base rock.

6. The truss bottom chords and rail beams are continuous longitudinally and securely bolted down to the pier tops (where.generally no movement could be discerned - except Pier 4 downstream side - see below). Thus it may be concluded that the whole deck of the bridge has moved north as a unit a distance of 4 " taking the pier tops at Piers 2 and 4 with it.

7. If the data of Figure 3.1 is now referred to it may be deduced therefore that at the water levels :-

Pier 2 has moved south $1 \frac{1}{2}$ to $2 \frac{1}{4}: "$

Pier 3 has not moved

Pier 4 has moved north $1 \frac{3}{8}$ to $4 \frac{3}{4}: "$

8. At Pier 5 which, according to the original plans, was built with a vertical front face, there is now on the upstream side a 2 " forward lean (Figure 3.1). This, when taken with the known 4 " northward. movement (see above) of the entire bridge deck, means a shortening of $6 "$ in the end panel of the bridge on the upstream side. This checks with the measured $6 "$ shown in Figure 1.2 where the truss base has remained firmly bolted to the concrete abutment so that the 6" movement has been concentrated in buckling of the steel lower chord of the truss. It also checks with the measured $7 "$ shown in Figure 1.3 where the rail beam has sheared the through bolts attaching it to the corbel and ridden forward over the concrete abutment a distance of $7 "$.

On the downstream side at Pier 5 similar effects have occurred. The 4" northwards movement of the deck has produced a 2 "buckling in the lower chord panel of the truss. The reason for the 2 " discrepancy in these measurements is obscure but may be partly explained by the general lengthening required in the whole of the downstream trusses due to the substantial downstream movement of the top of Pier 4 (Figure 3.2).

Despite the forward (i.e. southward) movement of the top of Pier 5 ( $2 "$ on upstream side), no signs of damage to the pier or its connecting wing walls was seen. 
9. At Pier 1 serious damage occurred to the pier - damage which is perfectiy consistent with the deformations imposed on the pier.

From Figure 3.1 it is seen that the top of the pier was dragged north some 5". This checks with the northwards movement of the entire deck of $4 "$ to which must be added $\frac{1}{2} "$ of chord shortening on the downstream truss and 2 " on the upstream one.

The pilaster under the upstream truss was wrenched away from the general mass of the pier (Figures 2 and 2.3) and in addition the abutment separated from its wing wall: the broken abutment moved forward (north) 6" (Figure 2.4) and the wing wall tilted out (Figure 2.3) one foot approximately (measured at the top of the wall), the base remaining fixed.

The pilaster under the downstream truss and jts attached wing wall survived these movements without apparent rupture. About halfway up this pilaster, however, a crack (appears on lefthand side of Figure 2.2) about 1/16" wide ran horizontally across the pilaster face. A vertical section through this pilaster parallel to the bridge longitudinal axis would now appear curved out (northwards) about halfway down.

3.3 Description of the Lateral Displacements suffered by the Bridge during the Earthquake:

The evidence of lateral movements of the bridge is presented in Figures 3 and 4 from which the following deductions may be made.

1. Piers 1, 2 and 5 suffered no permanent lateral displacements.

2. At Pier 3 the plumbline measurements, offsets and levels, when compared with the known height of pier and depth of cylinders as shown on the plans, are all consistent with the hypothesis that the pier and cylinders behaved as a rigid unit rocking on the cylinder bases. There was no permanent relative rotation at the cylinder-pier junction.

The pier moved sideways $10^{\prime \prime}$ at rail level, is out of level 2.3" across the deck surface and thi cylinder bases have therefore moved (lifted or sunk) $3^{\prime \prime}$ relative to each other.

3. At Pier 4 the same hypothesis is consistent with the measurements if the cylinders were founded 7 ft shallower than shown on the drawings.

In this case the pier moved sideways (downstream) $18 \frac{3}{4} "$ at rail level, is out of level 5 " across the deck surface and the cylinder bases have lifted or sunk $6 \frac{3}{4} "$ relative to each other.

If the cylinders were in fact built to the full depth shown on the plans then the measurements taken are consistent only if in addition to the above movements the pier-cylinder junction moved upstream $3 \frac{1}{2} "$. This corresponds to a rotation of the cylinders at their junction with the pier of 3.5

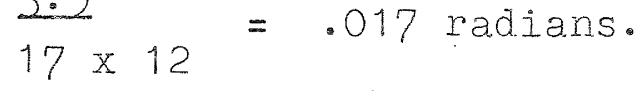

Some of this lateral movement at Pier 4 had occurred before the earthquake and is reported to be due to heavy flood debris loads. 

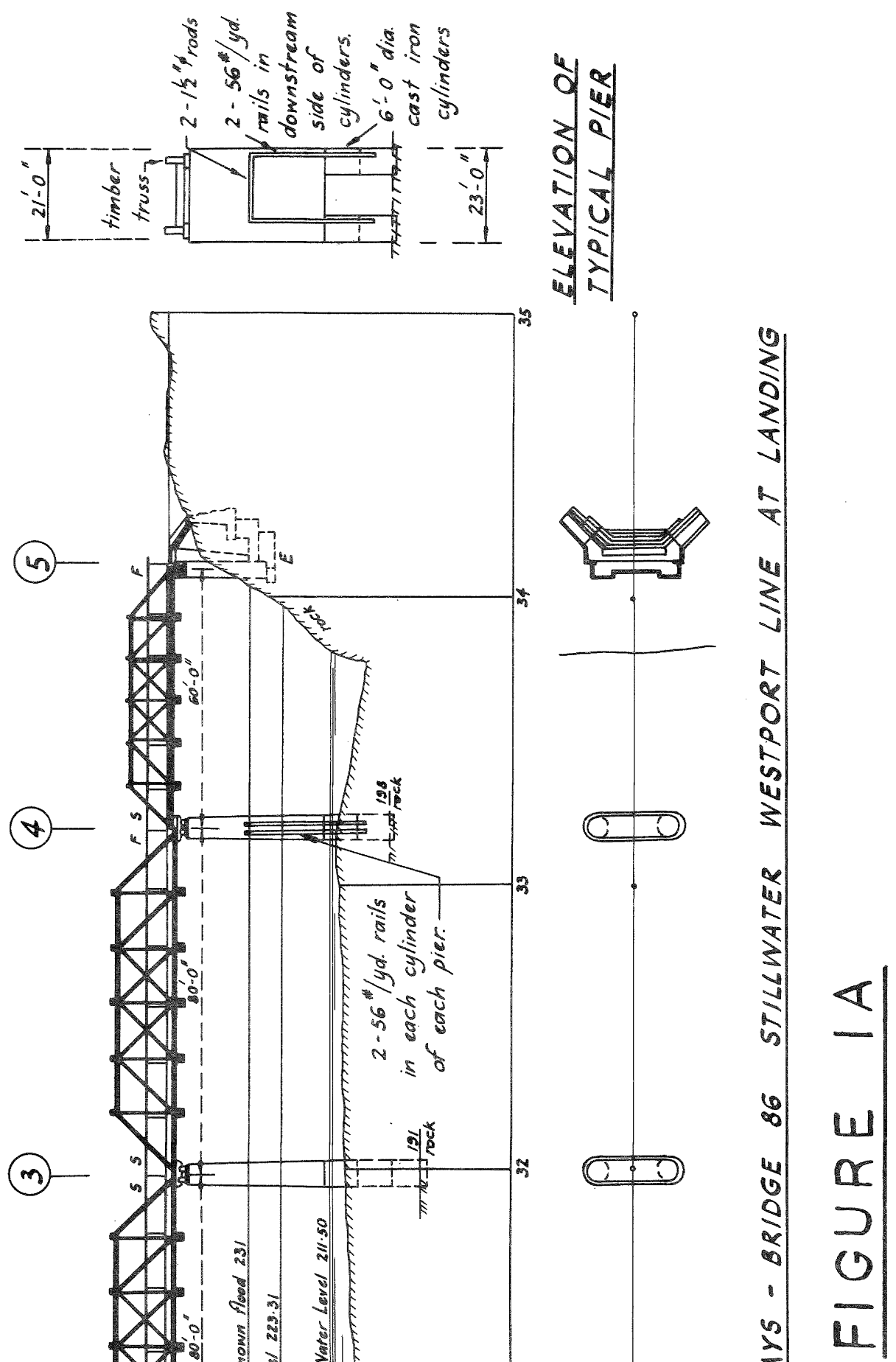

(n)

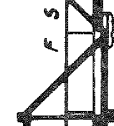

nr.
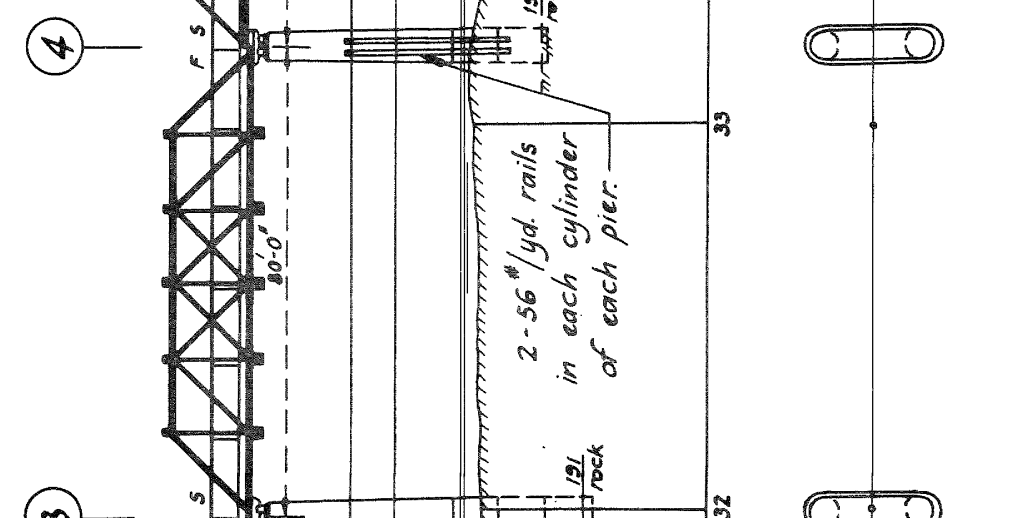

.

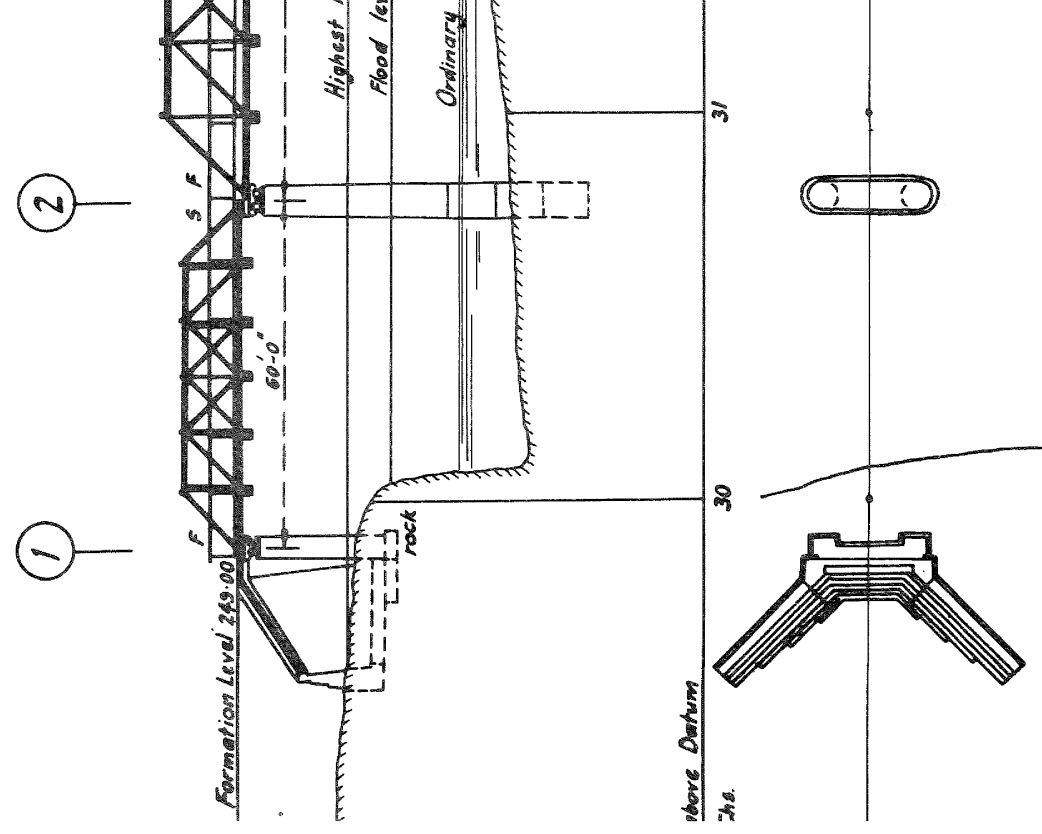

1
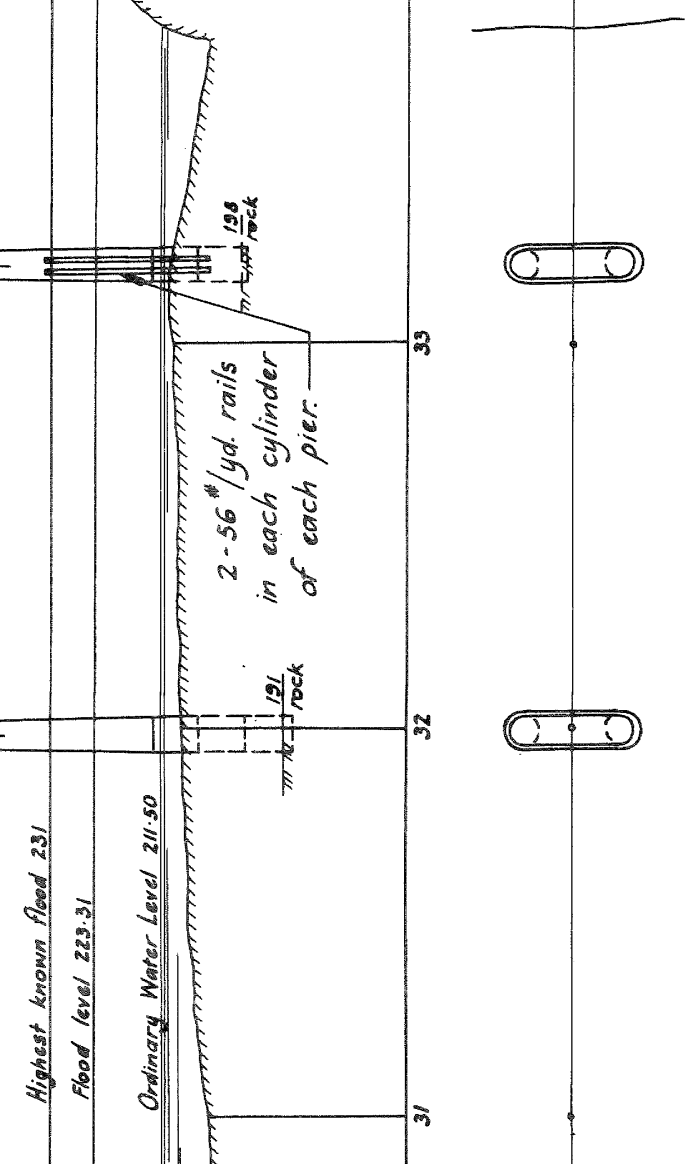

$<$

L) 


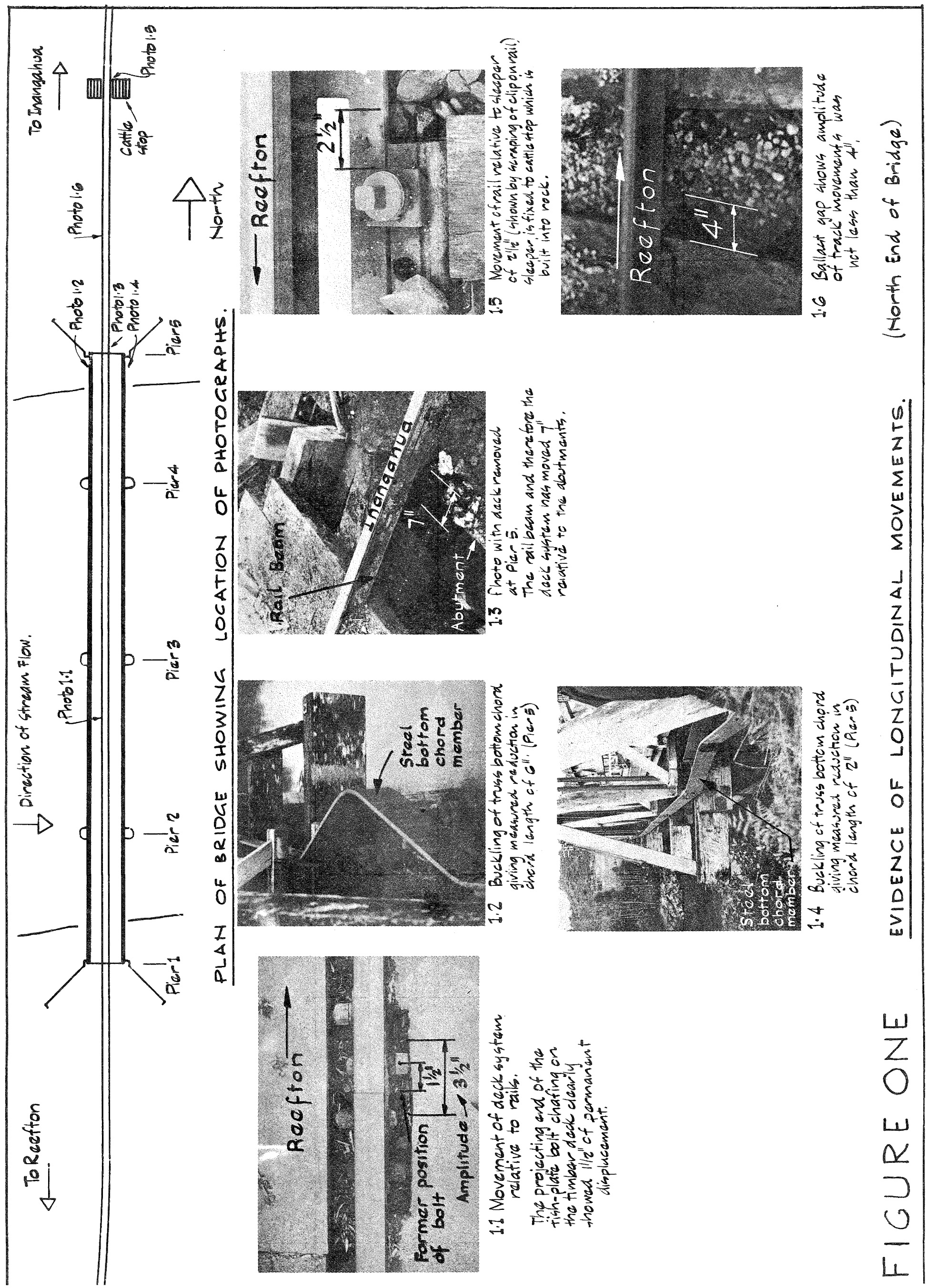




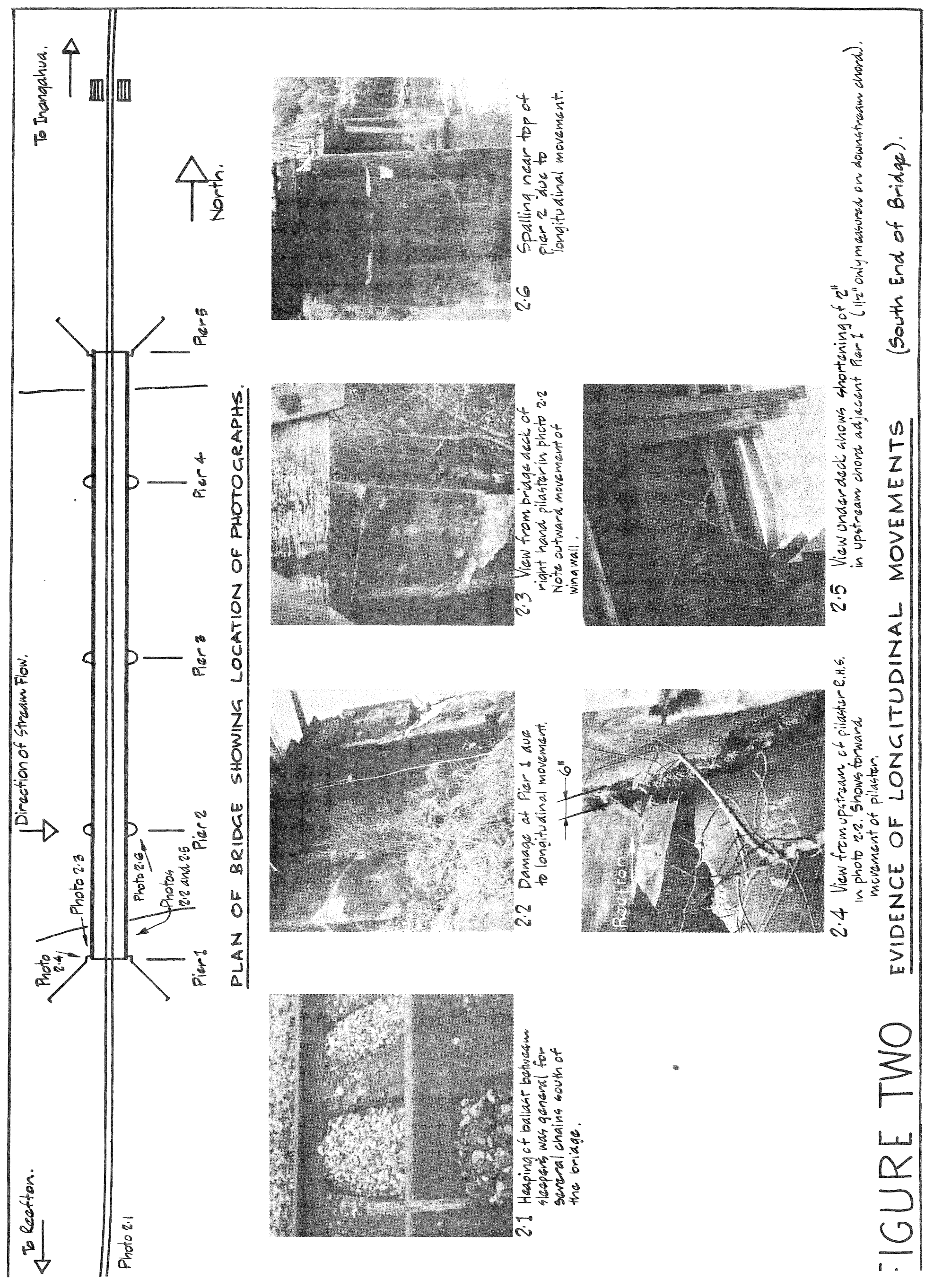




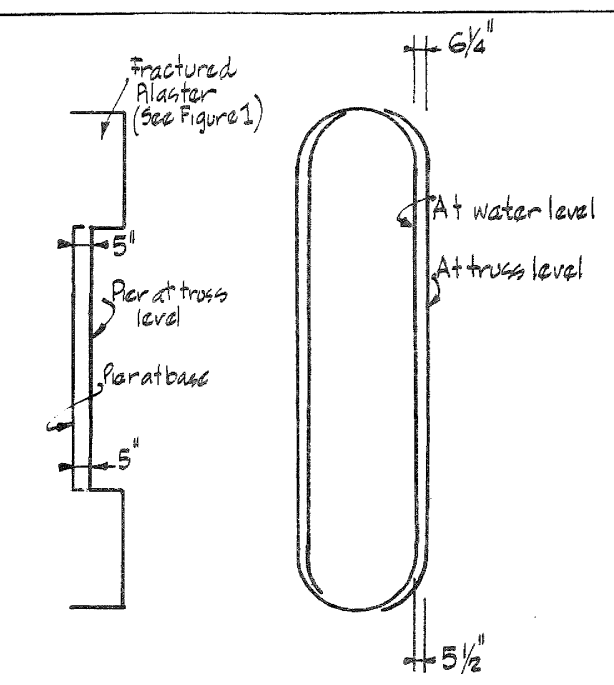

PIER 1

PIER 2

$$
\checkmark \text { Rection. }
$$

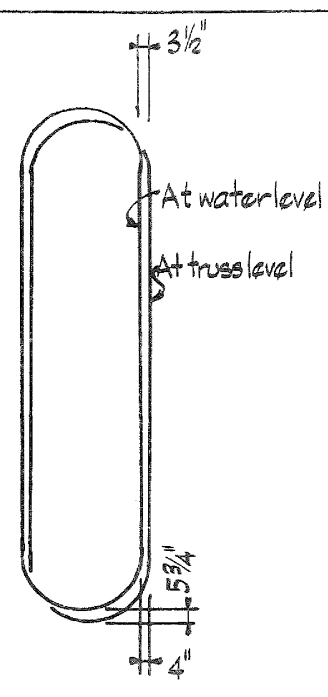

PIER 3

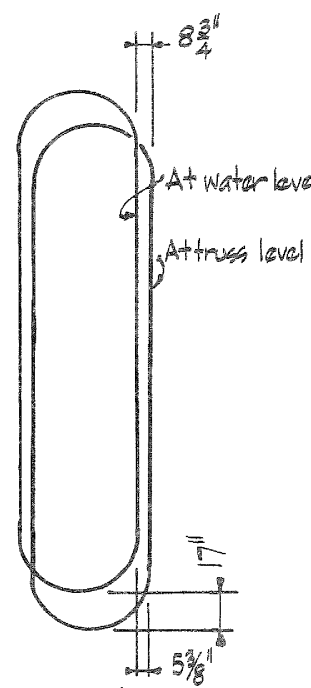

PIER 4

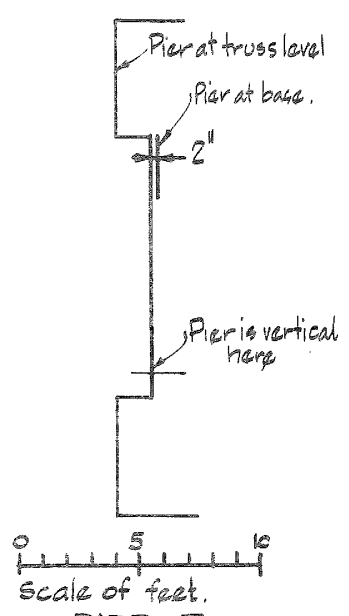

PIER 5.

PIER INCLINATIONS OBTAINED BY PLUMBLINE. (PlanView) FIGURE 3.1.

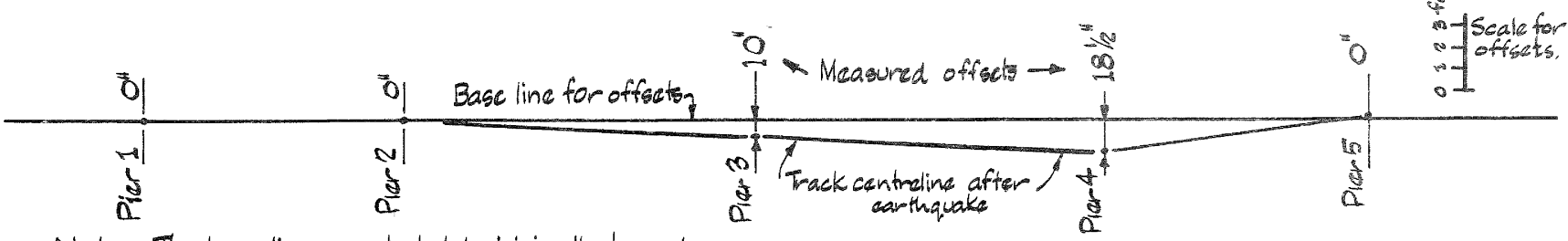

Note:- The base-line was selected by joining the tangent point of the approach curves to the bridge.

$\checkmark-$ Recton

North to Inangahua $\longrightarrow$

HORIZONTAL OFFSETS AT PIERS - (PlanView)

FIGURE 3.2

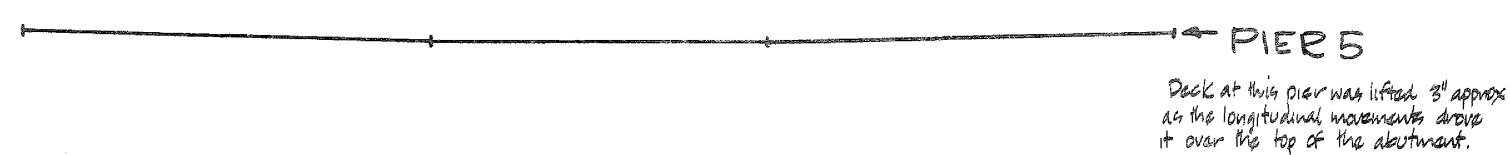

ah the longitudinaly movemente drove

PIER 1

a pier?

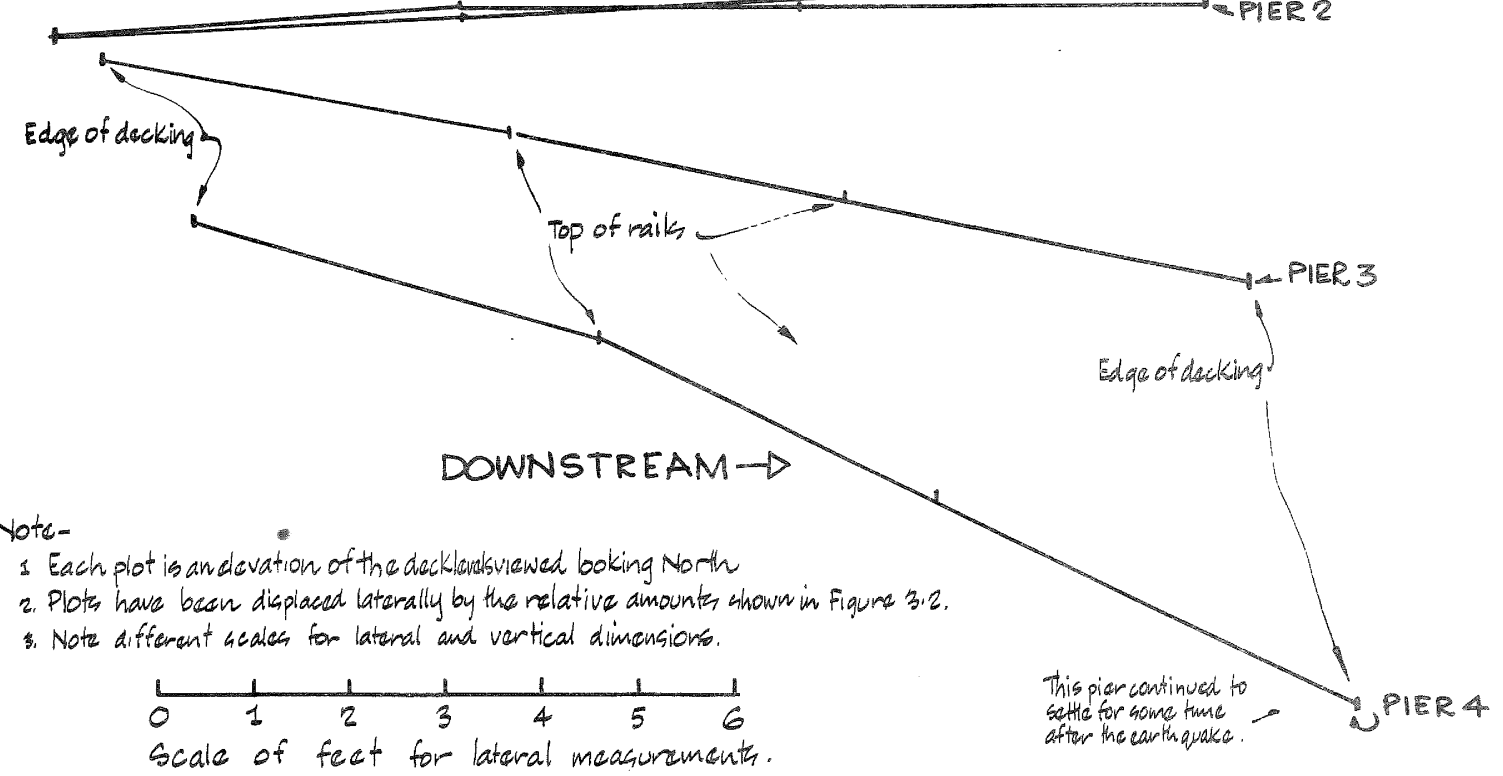




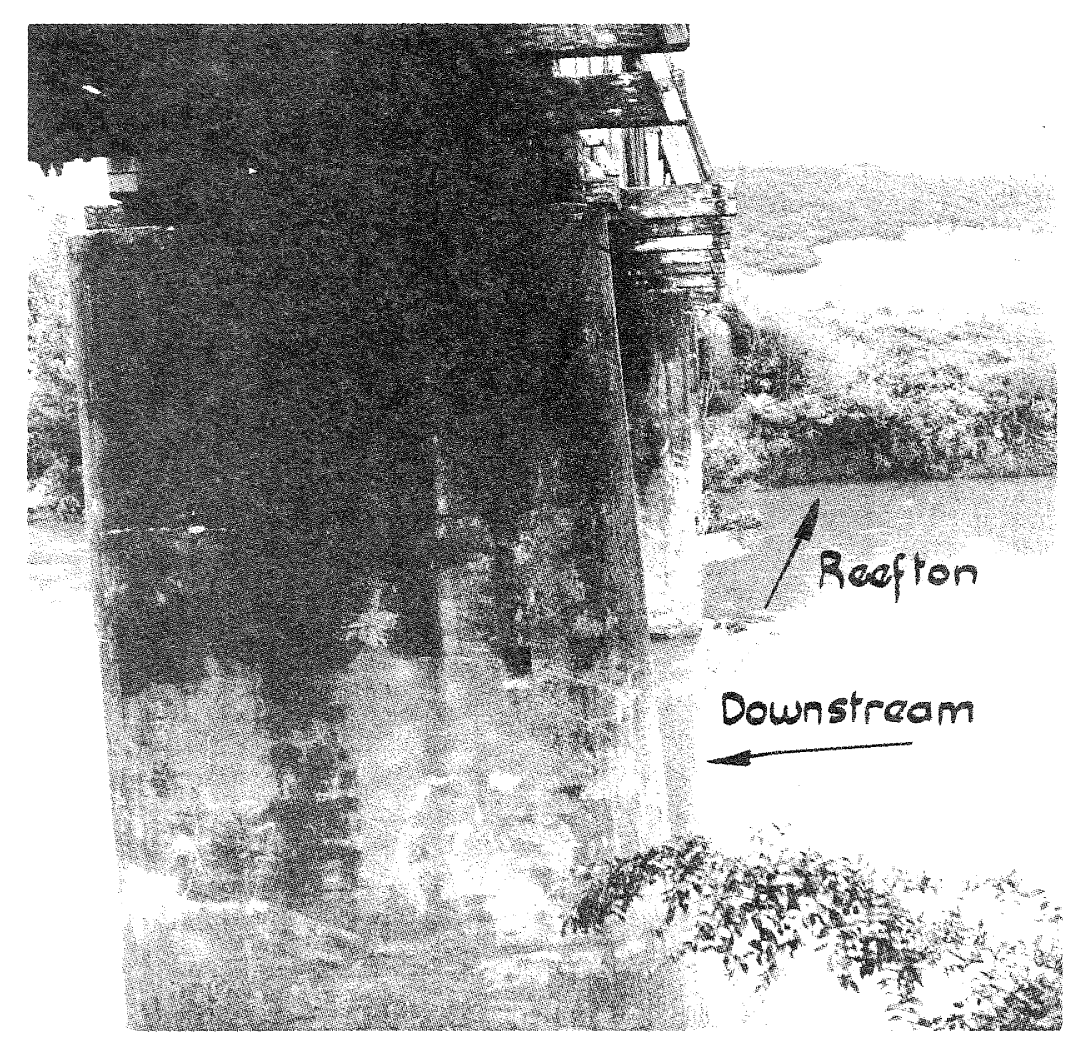

4.2 showing lateral displacement of pler 4

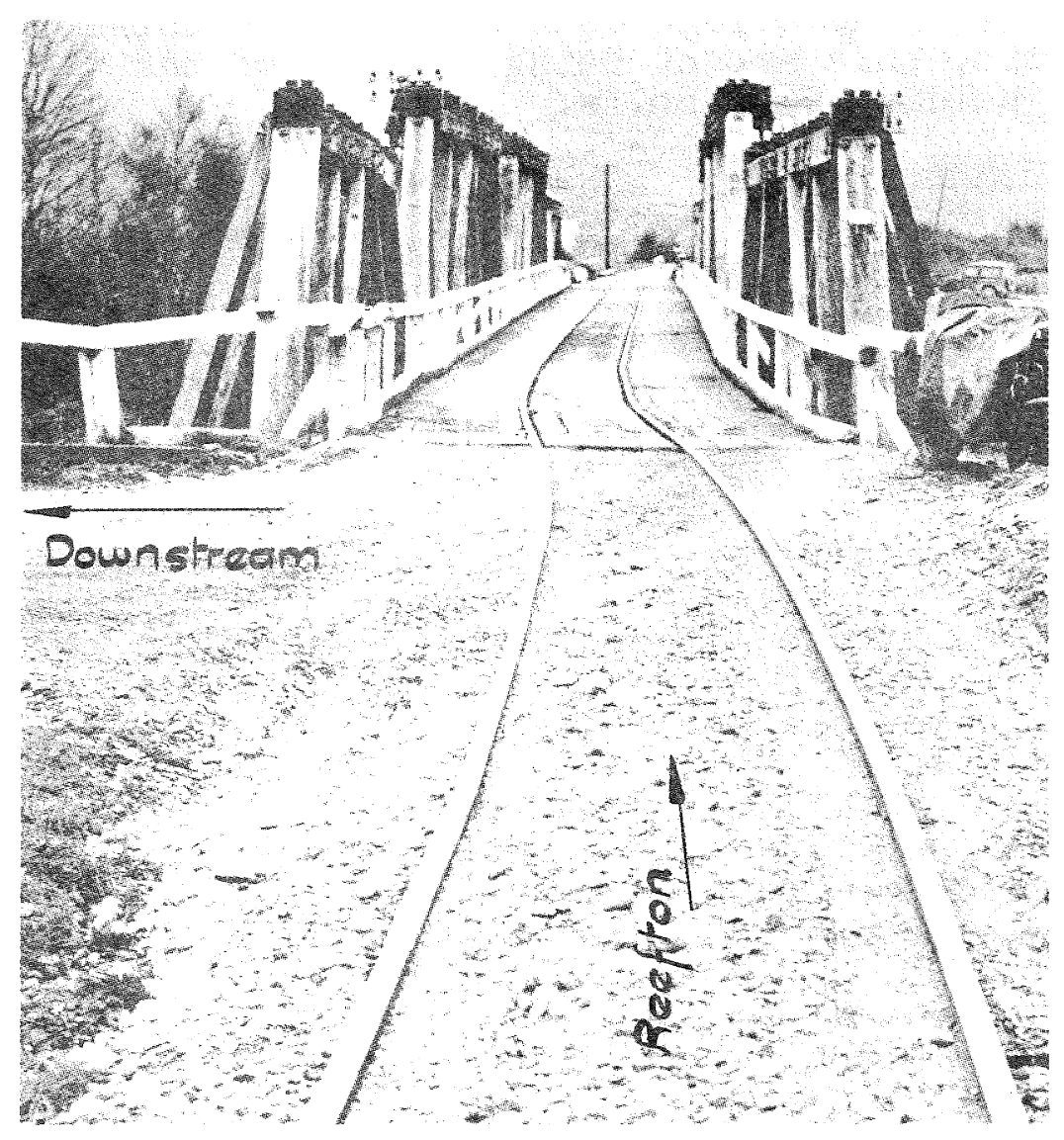
4.1 Showing lateral displacement of ralls at pier 4

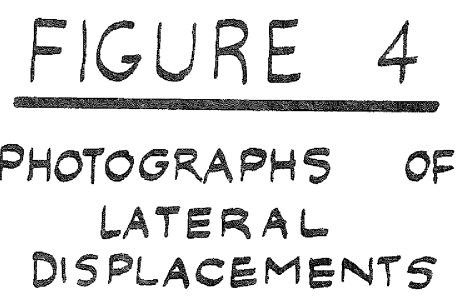




\subsection{Report on earthquake damage to the Buller, rail bridge on 24.5.68:}

\subsection{General Description:}

The Buller rail bridge, which was built in the late $1930^{\circ} \mathrm{s}$, is a 680 ft long bridge in which the six main spans are looft long throughtype rivetted steel plate girders simply supported on reinforced. concrete piers. The piers are on two $8 f t$ diameter cylinders sunk to bedrock which is a silt stone of the Miocene epoch (papa). This rock is overlain by up to 70 ft of river gravel at the north end of the bridge and rises to ground level at the toe of the south bank, see Eigure 5.4 .

The south abutment is founded on rock and the north abutment is founded on five 16" octagonal 50ft long reinforced concrete piles driven into the natural river gravel.

The bridge was inspected at all joints where all displacements and deformations were measured. These are plotted in Figures. 5 and 6. The lean on the piers was measured by plumbing and this is plotted in Figures 5.2 and 6.2. Slip in holding down bolts, rail levels, and the offsets of the rail centreline from a straight line between abutment centres are also plotted in Figures 5 and 6.

\subsection{General Pattern of Dj.splacements:}

Generally the whole bridge was moved south; mainly at the north end, which has also moved west. The bridge deck shortened a total of $19 \frac{1}{2}$ inches between abutments, this amount being the sum of the slip of all girders at their holding down bolts.

The formation for about 100 ft north of abutment 9 has fallen several feet, the maximum being 4'-6" at the abutment - see photo 7.2 . This settlement has occurred in a 20 ft deep embankment overlying $45 \mathrm{ft}$ of natural gravel in this :egion. Abutment 9 is on concrete piles which do not reach bedrock and has settled approximately 9 inches see Figures 5.4 and 6.4 .

\subsection{Holding Down Bolts:}

The main 100 ft span girders are fixed to the piers by four baseplates bolted and keyed to bedplates which in turn are bolted to the piers - see photo 8.3. One end of the girder is fixed where the key and bolts are a neat fit, as in photo 8.3. Allowance for sliding is made athe other end by elongating the bolt hole in the baseplate and widening the keyhole in the bedplate. However, examination of working drawings reveals that allowance for key movement is $\frac{1}{2}$ greater than for bolt movement. Hence the four $1 \frac{1}{2}$ " diameter bolts must carry all the shear from one end of a girder to its pier until these bolts are at least partly failed. The two types of joint are labelied "fixed" and "sliding" in Figure 5.3.

All bolts in "sliding connections" to the main spans have partly failed while only one of the bolts in a "fixed" connection has failed see Figure 5.3 . 
The baseplates and bedplates for the end spans have 1 $\frac{1}{4}$ in. diameter bolts with no keys. The abutment end is "fixed" and the pier end is "sliding", having elongated boltholes. All holding down bolts to end spans sheared off, see Figure 5.3 and photos 8.1 and 8.2 .

\subsection{Longitudinal Displacements:}

The total longitudinal movement of the piers and deck is shown in Figure 5.4 The displacements of piers relative to each other are taken directly from measurement but the absolute movement of the bridge as a whole has been deduced on the basis of two simplifying assumptions.

If it is assumed that bedrock has not moved and that the only curvature in the piers is at the failure at ground level, the absolute movement of the piers can be determined from the measured lean above ground level. Thus Pier 7, which is the only pier without visible failure can be approximated as straight and its total deflection determined from its slope above ground level - see as in Figure 5.4.

As the relative displacement of all piers is known, this fixes the absolute deflections of all other piers at their top and at ground level. The deflected position of the cylinders below ground level has been plotted from measurement of crack widths and simple calculation assuming all bending curvature occurs at this crack. As can be seen in Figure 5.4, these uerived positions of the cylinder bases are in every case consistent with their original positions. The assumptions therefore seem justified, even if only to determine the absolute displacements to the accuracy of this investigation.

Generally, both abutments have been pushed inward by a combination of embankment settlement and fill material falling behind the abutment during longitudinal oscillations of the bridge deck.

Piers 2 and 8, at the toe of the river banks have also been pushed. toward the river at ground level where bending failures have occurred. through a pier construction joint in Pier 2 (See photos 10.1, 10.2 and 10.3) and at the junction of Pier 8 with its cylinders. (See photo 10.4). There is also a 2 inch shear displacement at Pier 2. These severe bending failures have probably been caused by debris falling behind the pier during longitudinal oscillations and also by southward movement of the river gravel and embankment at the north bank.

\subsection{Lateral Displacements:}

The north embankment fill and possibly river gravel has also moved. to the west. Figure 6.3 shows the total lateral pier movement combining measurements of offsets from a line between abutment centres, plumbing and crack width at ground level. Again the measured crack widths at the pier failure are consistent with the two assumptions that bedrock has not moved and all pier curvature is concentrated at the failure at ground level.

The river gravel in the region of Piers 7 and 8 appears to have moved west taking the piers with it. The deck north of Pier 6 has been pulled west resulting in the failure of the west holding down bolts for girder 6-5 (see Figure 5.3) and a $\frac{1}{2}$ " crack on the eastern side of Pier 6 (see Figure 6.3). The top of Pier 8 appears to have been restrained by the deck as there is a crack in the western side of the base of this pier, - see Figure 5.3. 
All piers, except No. 7, have diagonal tension cracks at ground level, passing from the bottom centre of the web running at 300 to 450 through both columns, - see photos 9.1 and 9.3 . These are probably due to sideways oscillations of the pier tops when there exists a condition of horizontal and vertical tension above one of the piers. In the web of Pier 6 there is also a vertical crack which runs nearly the full height of the pier, starting 3 inches from the edge of the east column and finishing at the top web centre. Pier 7 is the only pier with no visible cracking above ground level, in spite of major failure at the base of Piers 6 and 8. Rail level also appears to have fallen about one inch over this pier (Figure 6.4) and the ground around the base of the pier appears to have settled about 9", - see photo $7 \cdot 3$.

Pier 6 shows evidence of at least $1 \frac{1}{2}$ cycles of oscillation which could have been lateral or longitudinal or probably both - see photo 9.2 . 


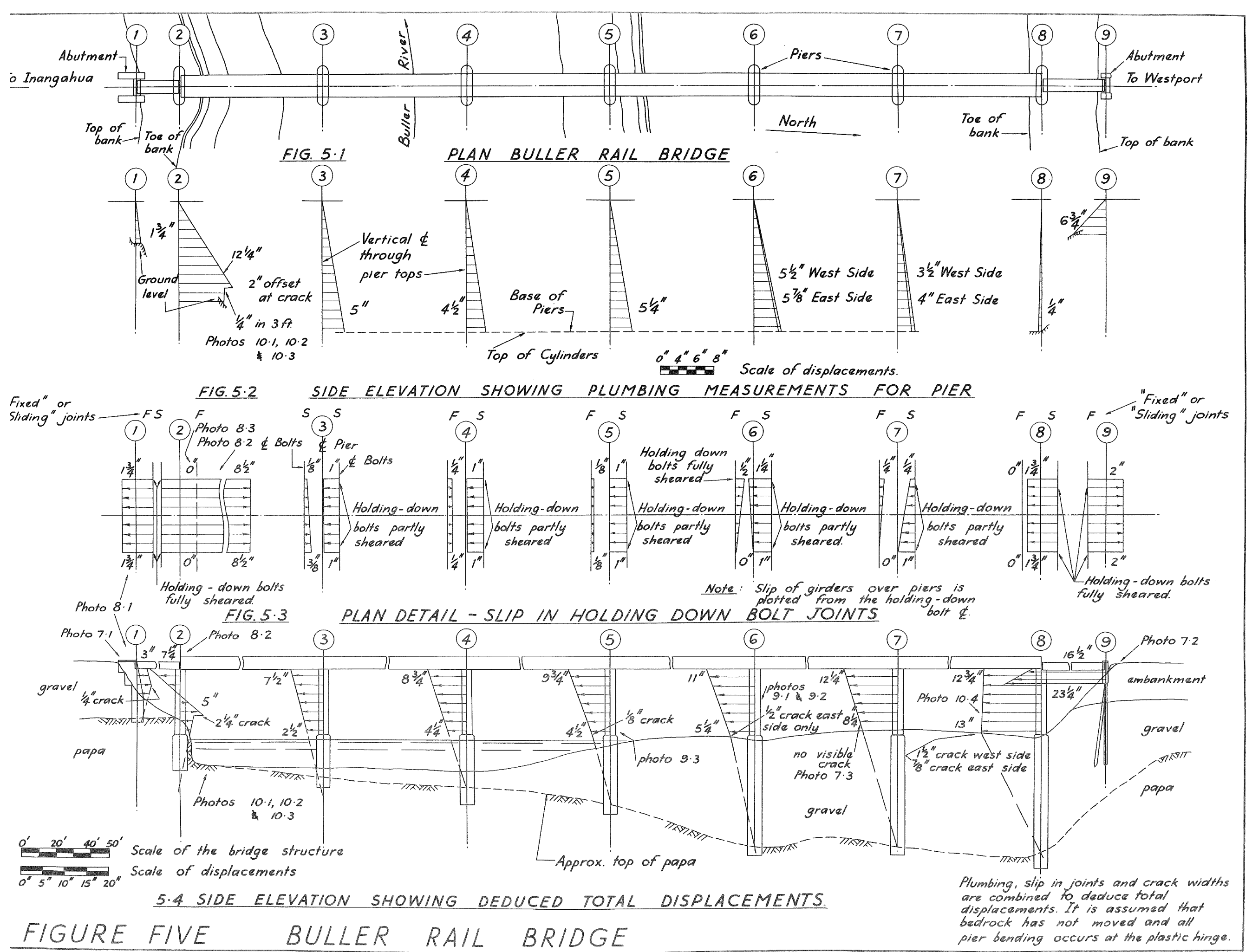



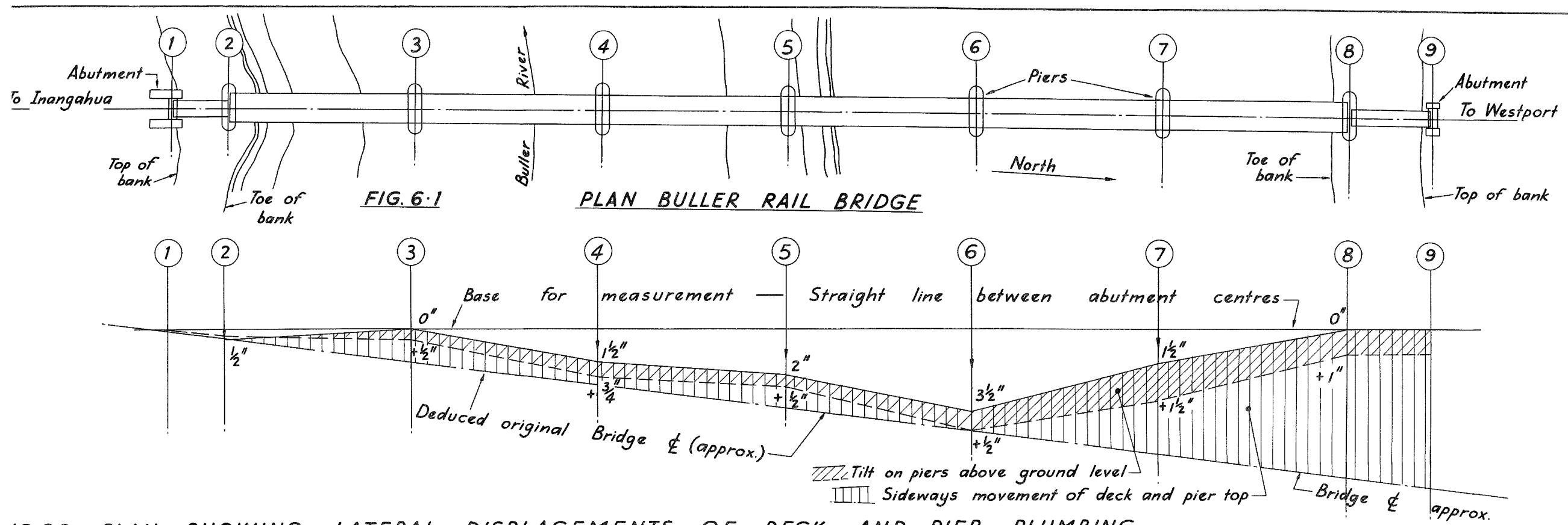

1G.6.2 PLAN SHOWING LATERAL DISPLACEMENTS OF DECK AND PIER PLUMBING

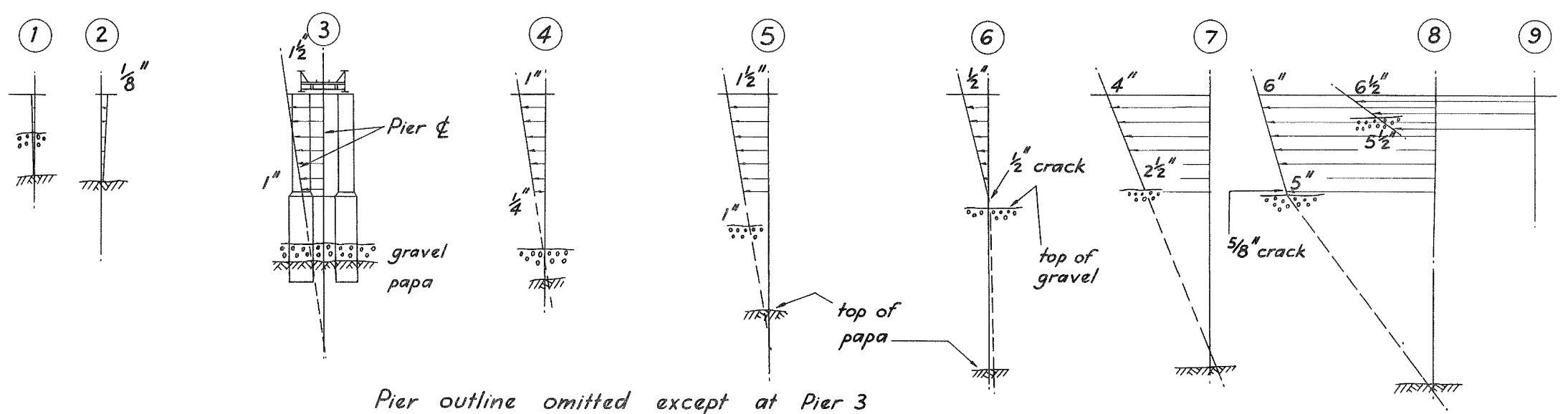

IG.6.3 SERIES OF ELEVATIONS OF PIERS LOOKING NORTH SHOWING LATERAL DISPLACEMENTS OF

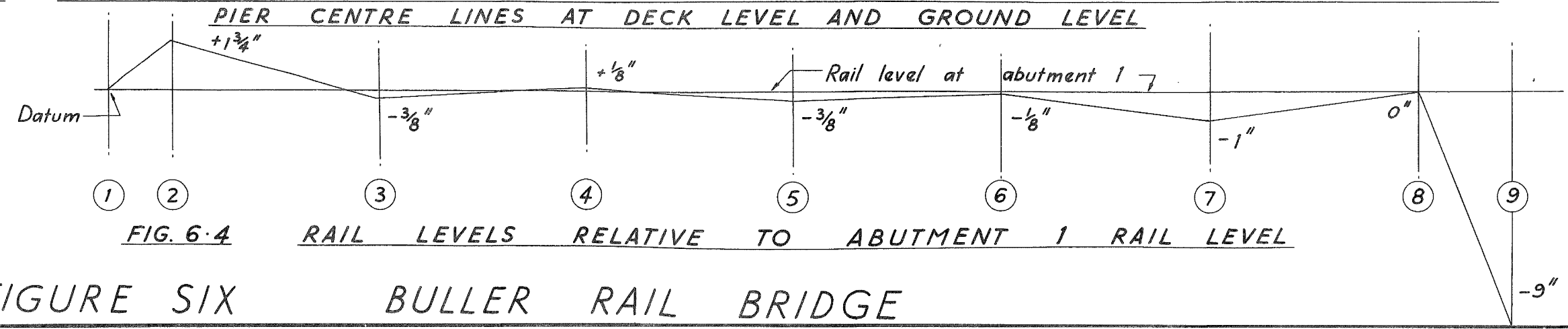



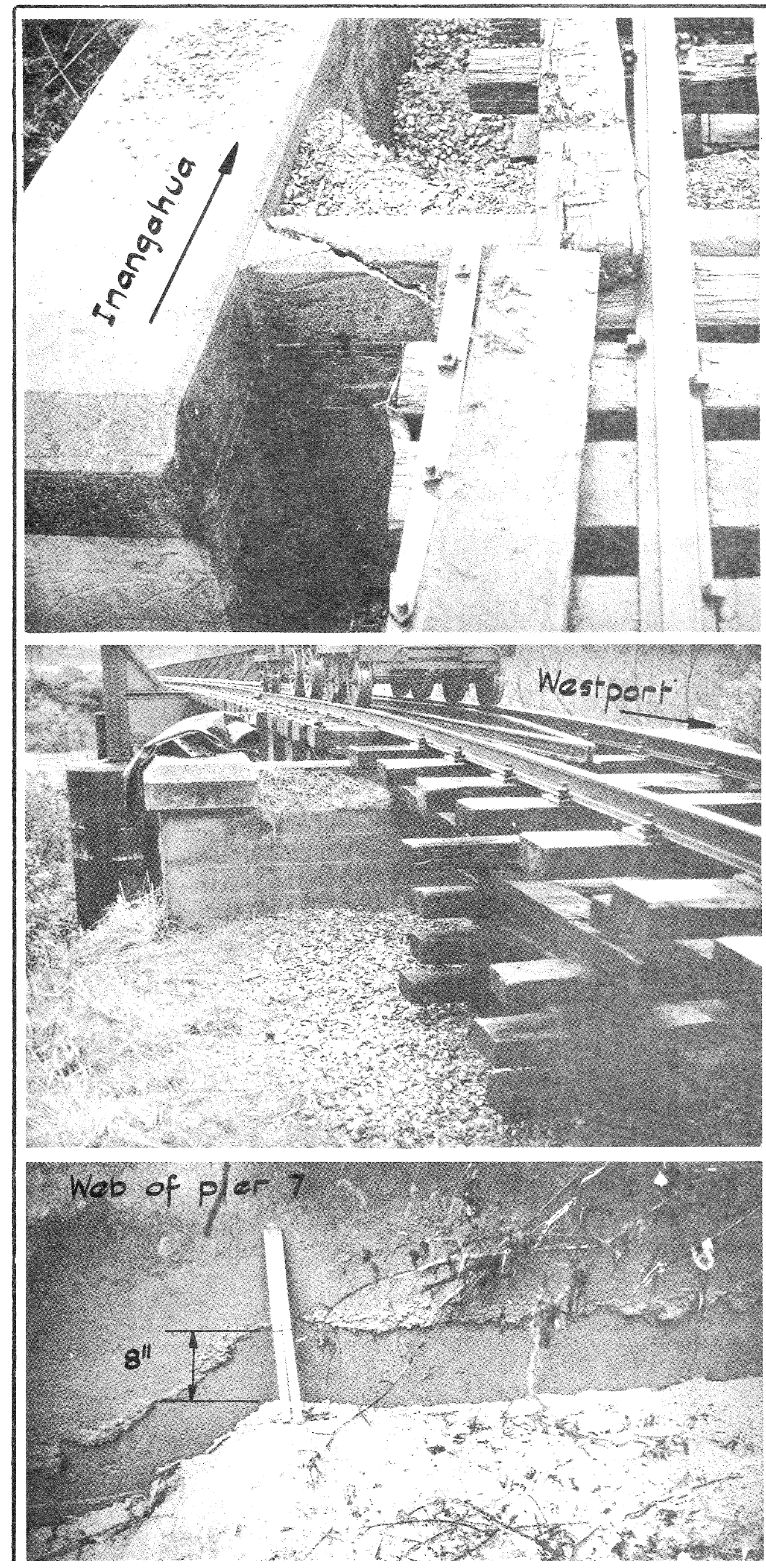

Photo 7.3: Bese of Pier 7 The surrounding ground has seltled 8II. Bedrock (papa) is overlain by $70 \mathrm{ft}$ of river gravel at this point

Photo 7.2: Abutment 9 embankment has settled 4'.6"l for $100 \mathrm{ft}$ past the abutment which itself setrled gll

$\frac{\text { Photo } 7 \cdot 1 \text { : Abutment } 1}{\text { (South) Note cracked }}$ wall and setpled ballast behind obutment

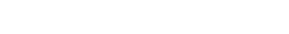



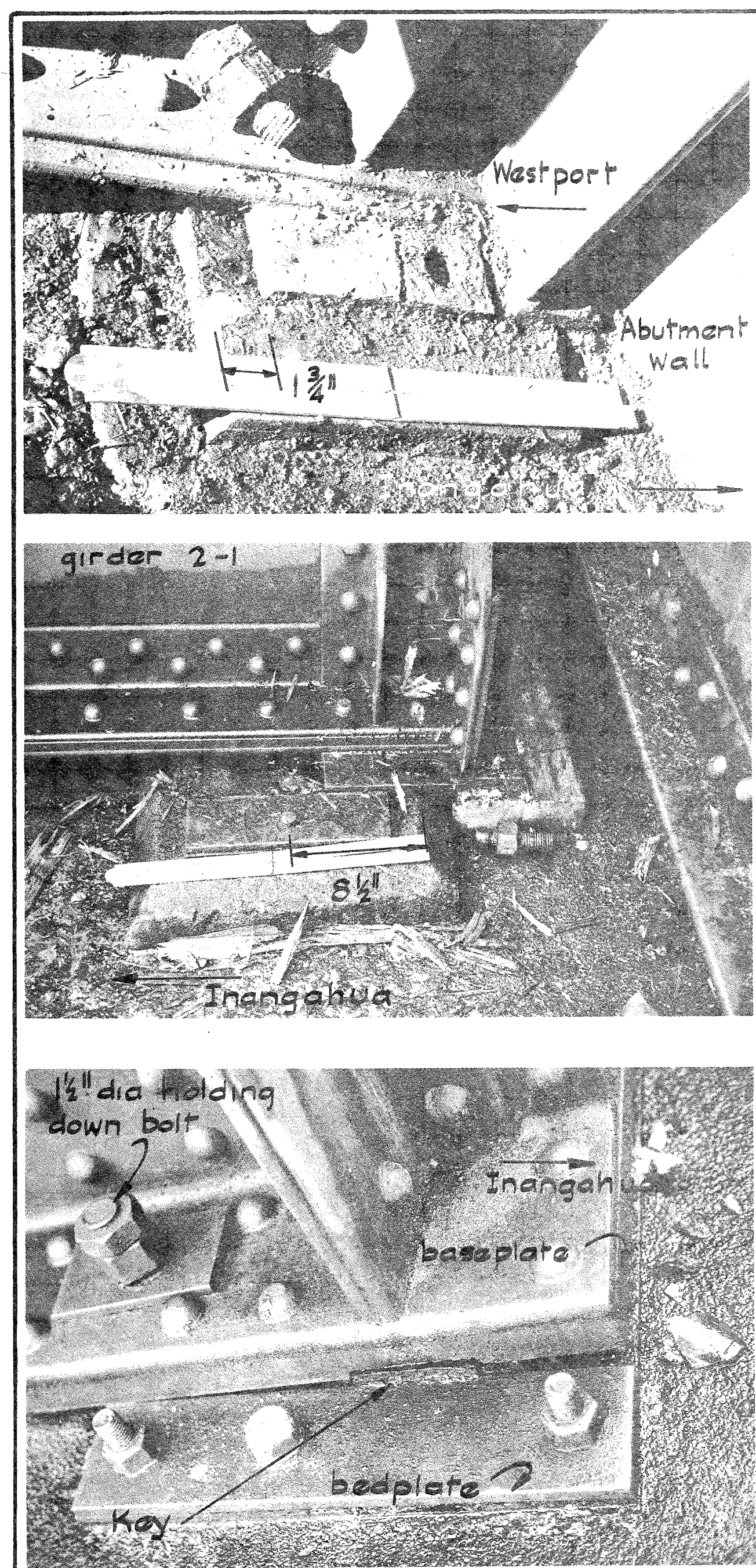

Photo 8.1: Abutment 1 has sheared and the girder thrust against the abutment wall.

Photo 8.2: Girder 2-1 at pler 2 Holding-down bolt has sheared and the girder slipped 81/2". Note the elongated hole for a "sliding" joint.
Photo 8.3: Girder 2-3 at pler "2 connection of $100 \mathrm{ft}$ girders to pier. Note key and slope due to lean on pier 2 


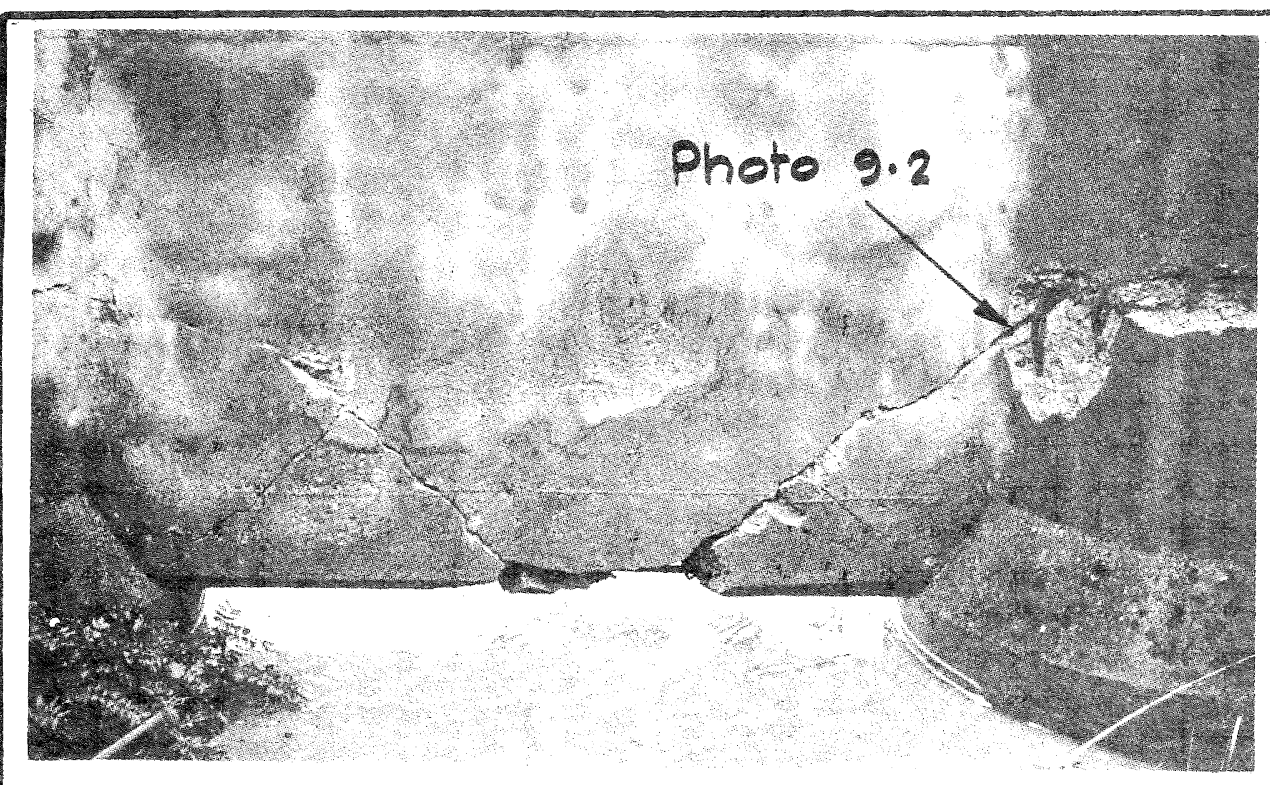

Photo 9.1: Pier 6

level north face, south face similar. Note the diagonal tension cracks and the reinforeing bars which have buckled after yielding.

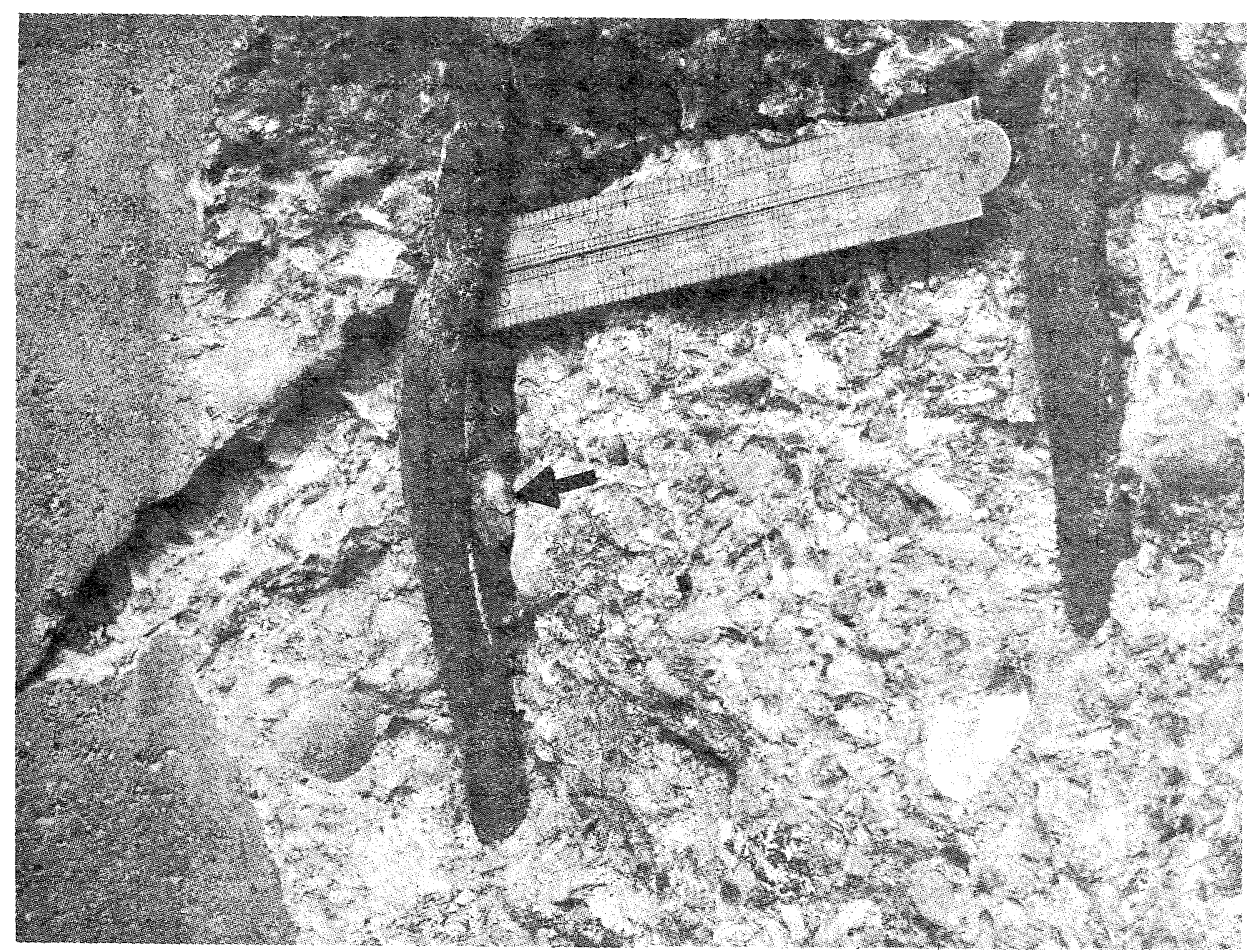

Photo 9.2: Piar 6 Detall from photo 9.1 Note the marked plece of aggregate behind the left bar. This stone fell behind the bar when it buckled and was later crushed by bar tension. The bai has sinee buckled again.

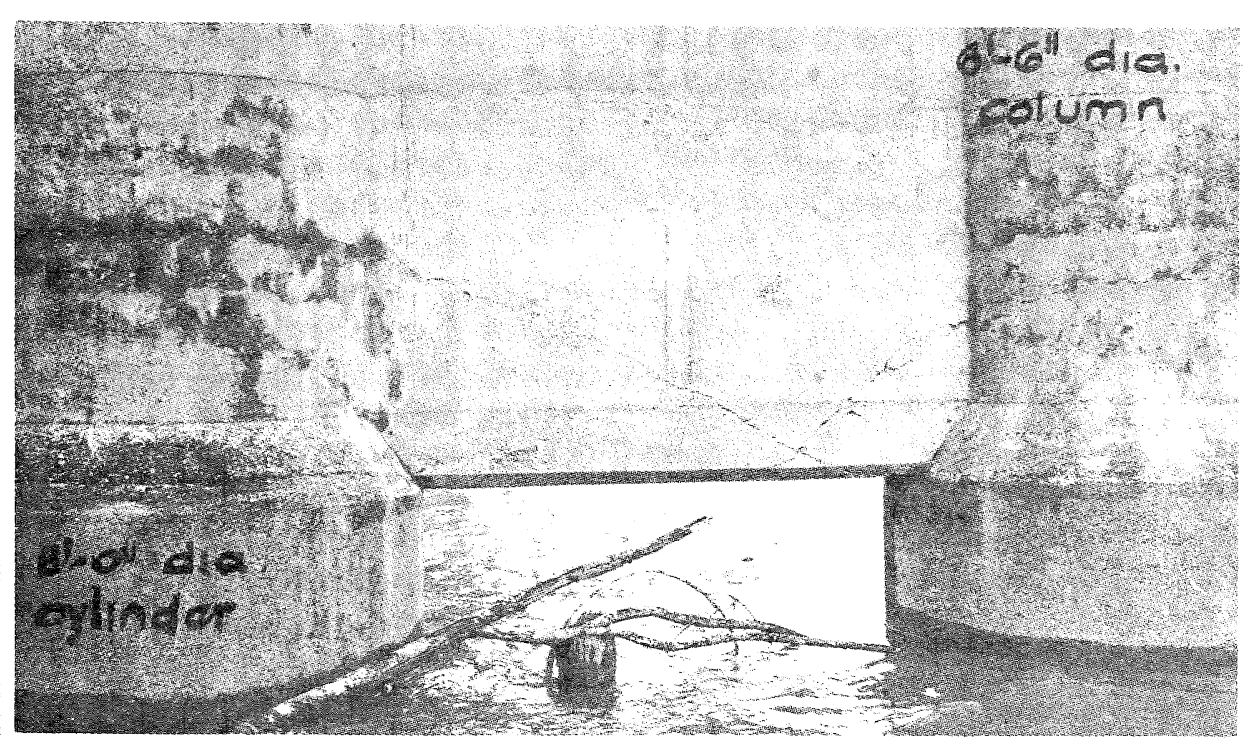

Photo 9.3: Pier 5

Farbure at ground level north face, south face similar. Diagonal tension. erack extends through wob and columns. Piers 3 and 4 are similar 


\subsection{Report on earthquake damage to the inangahua combined road and rail bridge on 24.5 .68 :}

\subsection{General Description of the Bridge:}

The bridge, which is a combined road and rail bridge, is 54 oft long consisting of nine $60 \mathrm{ft}$ spans of deck type rivetted steel plate girders. The rail and single lane roadway are separated and are supported by separate girder systems on the same reinforced concrete piers which are founded on two 6 ft diameter cylinders sunk to bedrock. The bridge was built in the mid 1920's and was previously damaged by the 1929 Murchison earthquake, but at that stage was being used for road traffic only and had no rail girders erected. The pier tops were displaced by up to $12^{\prime \prime}$ sideways and $1^{\prime}-2 \frac{1}{2} "$ longitudinally and the girders were subsequently erected on the displaced piers. The amount by which each pier was displaced when the rail girders were erected has been determined by measuring positions of the bedplates in relation to the top edges of the pier and comparing this with the original working drawings.

The displacements of the piers and abutments after the 1929 earthquake were reported in a paper by F.W. Furkert to the Institution of Civil Engineers 1933 (Proceedings Vol. 236) and are shown in Figures 11.3 and 12.3 by the position of the vertical arrows.

It is evident that the piers were not straightened before the erection of the railway spans because the relative displacements of the piers before the last earthquake are the same as those reported by Furkert. The railway girders were built in a straight line with their centreline concurrent with the rail centreline. They were each therefore offset slightly from the pier centreline. Also the girders were all moved approximately 8 inches south. relative to their position on the working drawings so that the 60 ft spans would fit as closely as possible over the displaced piers. (The mean southward pier displacement was approximately 8 inches).

In the recent investigation, lean on the piers, slip in holding down bolts, pier and rail levels and the displacement of the rail centreline were all measured. The present lean on the piers is the sum of the effects of both earthquakes; the sideways displacement of the rail (and hence girders and pier tops) in this last earthquake was found absolutely by extending south the centreline of the undisturbed rail in a long cutting immediately north of the bridge.

Figures 11 and 12 show the present displacements as measured, and the displacements after 1929 as reported by Furkert and confirmed by measurement.

\subsection{Longitudinal Movement:}

The bridge deck has moved longitudinally north-east as a whole with all pier tops moving in that direction. The movement is greater at the south-western end, but closing together of girders at the piers has reduced the movement at the north-eastern end. The deck has shortened a total of about 8 inches and the south-western abutment 1 , which is not founded on rock, has moved about $7 \frac{1}{2}$ inches toward the river. See photo 13.2 . 
This movement of' the abutment has probably been caused by settlement of the railway embankment to the south of the bridge, see photo 13.1, and by debris falling behind the abutment during longitudinal oscillations of the bridge deck. The southern piers, being connected. to the abutment by deck girders, have therefore been pushed northward, which is opposite to tho direction of the 1929 earthquake displacements. Holding down bolts did not shear off anywhere except at abutment 1. Except for the end spans, the north end of each girder appeared to be "fixed" by bolting through round holes in the baseplates and bedplates (no shear key), and the south end "sliding" having elongated bolt holes in the baseplate. This is not the arrangement of "f'ixed" and "sliding" joints shown on the working drawings but it is consistent with current practice on other plate girder bridges of similar construction ( $e . g$. Buller Rail Bridge at Inangahua). The end spans are "fixed" at the abutment and sliding at the pier.

There was generally a slip of about 1 inch at the "sliding" ends and in all cases but one the direction was to shorten the deck. The only bolts to be sheared off were the holding down bolts at abutment 1.

The road deck shows evidence of considerable longitudinal oscillations by spalling at the joints between precast deck slabs and failure and buckling of the handrails, see photos 14.4 and 14.5 .

The top handrail was embedded 8 inches in the abutment wall, allowing for the piece of concrete broken off the top of the wall. This rail was pulled fully out of the wall and later buckled just to the north of photo 14.4 .

\subsection{Lateral Movement:}

Lateral movement is generally an increase on the 1929 displacements, major movement being in Piers 2 to 6 . These piers have moved a further 2 to 4 inches west, - see Figure 11.2 and 11.3.

\subsection{Failure at Base of Piers:}

Piers 2, 3, 4, 5 and 6 all pailed just above ground level at the construction joint in line with the bottom of the web, see Figure 15 and photos $14.1,14.2$ and 14.3 . This is a definite weak point, being the bottom of the web and the cut off point of the hooked bars in the cylinders; the reinforcing bars that are continuous through this joint have threaded splices further reducing the area of reinforcing steel. Many bars buckled at this threaded portion (photos 15.2 and 15.3) and some broke (left bar in photo 15.2). It is possible that there have been concrete cracks in this area for some time, or the bars were not properly covered with concrete after the 1929 earthquake, as some bars appeared to be corroded - see photo 15.3.

There was no sign of failure or cracking above grourd level in Piers 7, 8 and 9 and it may be noted that the cylinders under these piers do not pass through. much gravel before reaching bedrock.

Both abutments, which are unreinforced mass concrete, cracked horizontally through the holes left for access to holding down bolts see photos 13.2 and 13.4. Abutment 1, which was in a rogion of considerable embankment settlement, had a crack width of 3 inches and a shear displacement at the crack of $3 "$. 
The railway embankment south of abutment 1 settled many feet for hundreds of yards, see photo 13.1, while the embankment north of abutment 10 settled about $3 f t$ for about looft before a cutting through rock, see photos 13.3 and 13.4 .

Except at the abutments it was not possible to attempt to correlate crack widths with the lean on piers because of the unknown cracking and method of fixing or patching of the pier failures during the 1929 earthquake. The centre lines of the concrete cylinders have therefore not been plotted in Figures 12.3 and 13.3 .

\subsection{Acknowledgements:}

Mr J. Bruce Wilson, Bridge Engineer N.Z. Railways, shared the measuring task at the Landing Bridge and has given valuable advice during the preparation of this report.

Without the assistance of $\mathrm{Mr}$ G. Bridges, Chief Civil Engineer, N.Z. Railways, in facilitating access to the bridge sites during the difficult period of reconstruction, this report would not have been possible.

The permission of $\mathrm{Mr}$ G. Bridges, Chief Civil Engineer, N.Z. Railways, and of Mr B. Spooner, Chief Civil Engineer, Ministry of Works, to publish this material is acknowledged. 


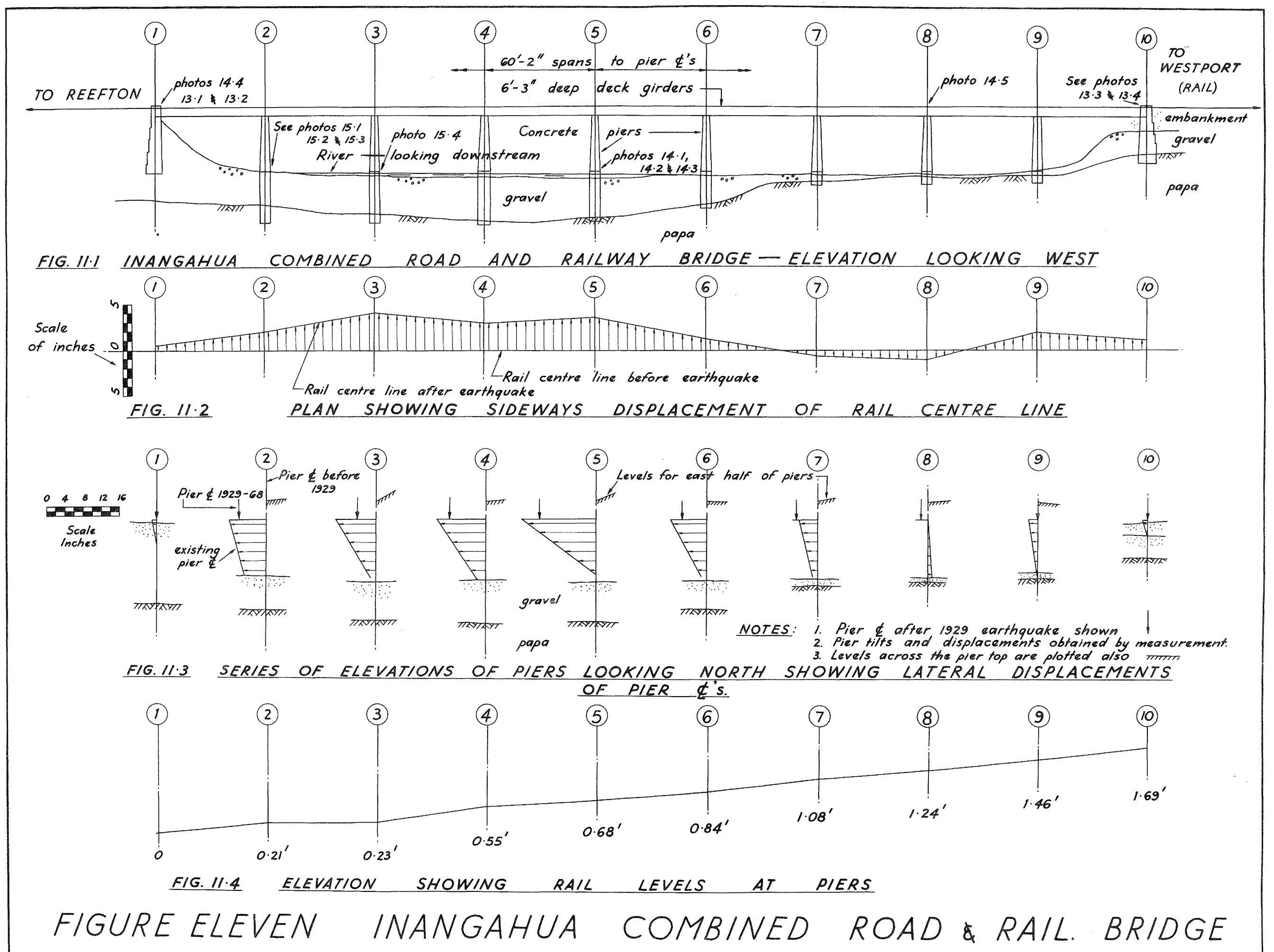




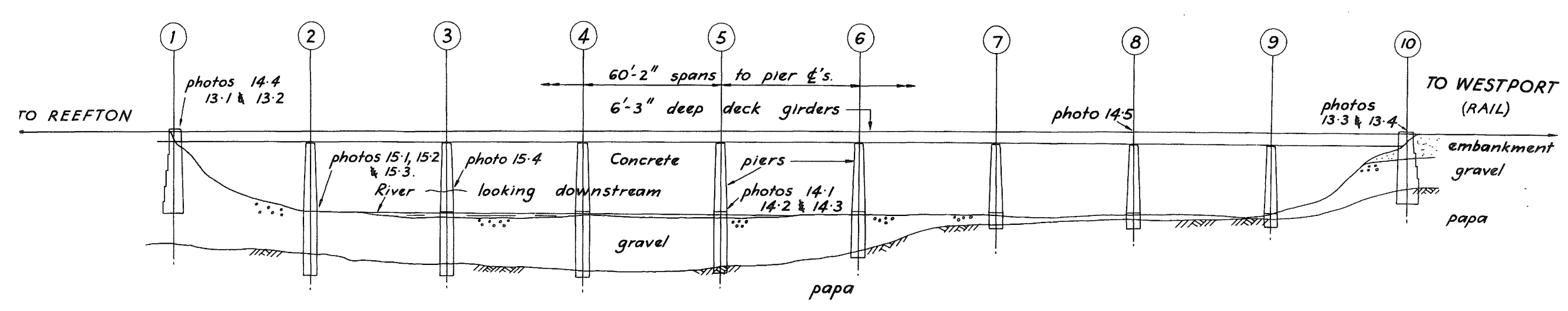

FIG.12.I ELEVATION - INANGAHUA COMBINED ROAD AND RAILWAY BRIDGE-LOOKING WEST.

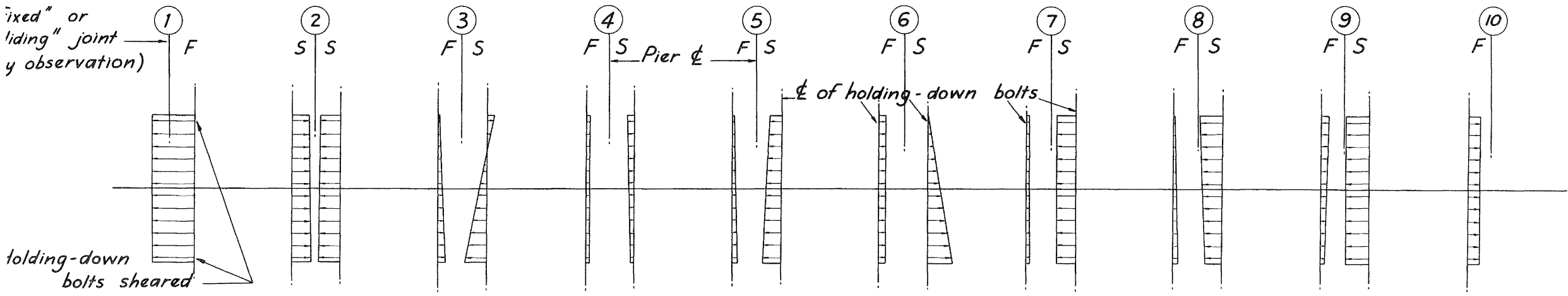

Scale of inches: Direction of Slip.

Slip of girders over piers is plotted from the bolt $\notin$.

FIG. I2.2 PLAN SHOWING SLIP IN HOLDING DOWN BOLT JOINTS

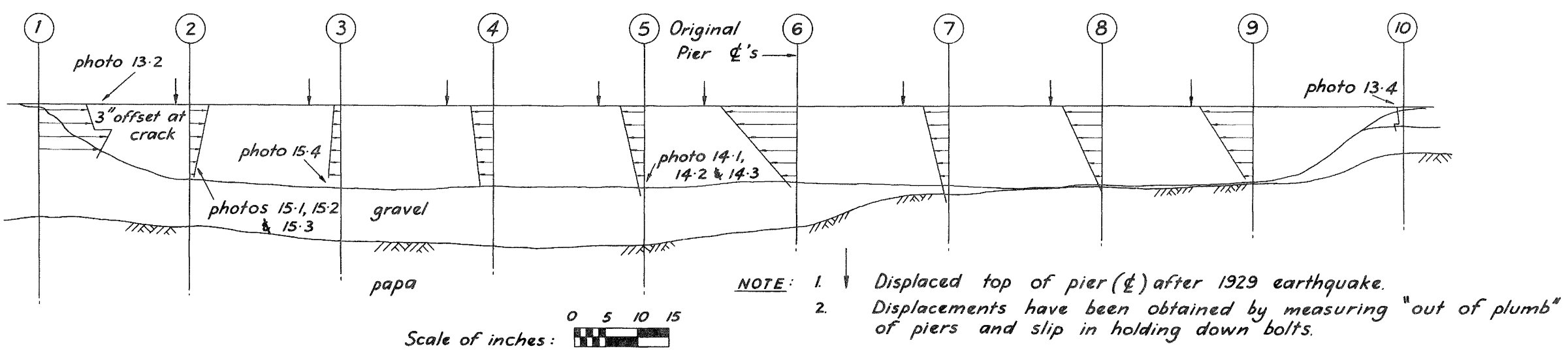

FIG. 12.3 ELEVATION SHOWING LONGITUDINAL PIER DISPLACEMENTS 

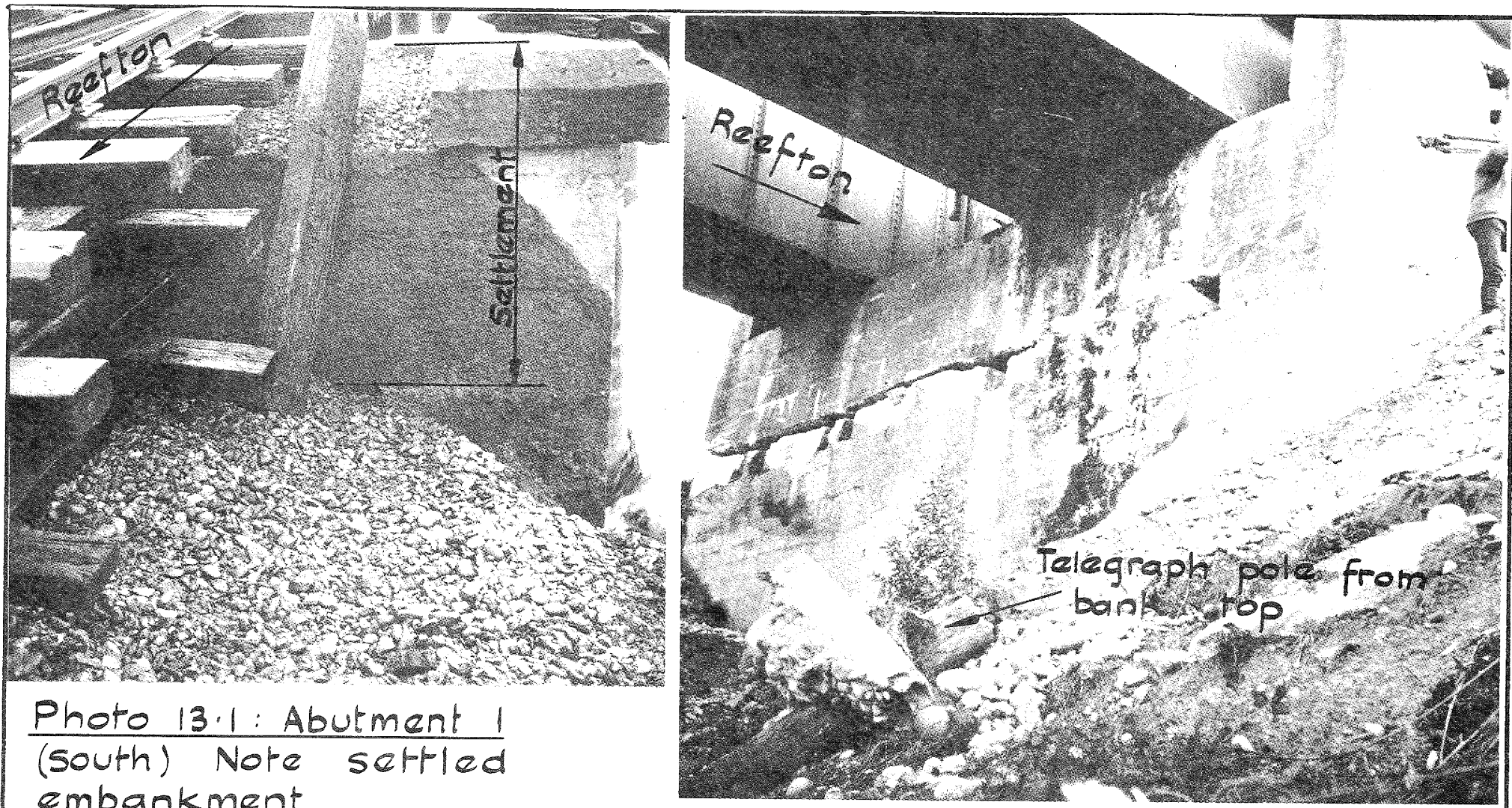

$\frac{\text { Photo 13.1: Abutment } 1}{\text { (south) Note settled }}$ ambankment

Photo 13.2: Abutment 1 Horizontal crack through holes for access to holding-down bolis in mass concrete abutment. Note debris sliding
down bank
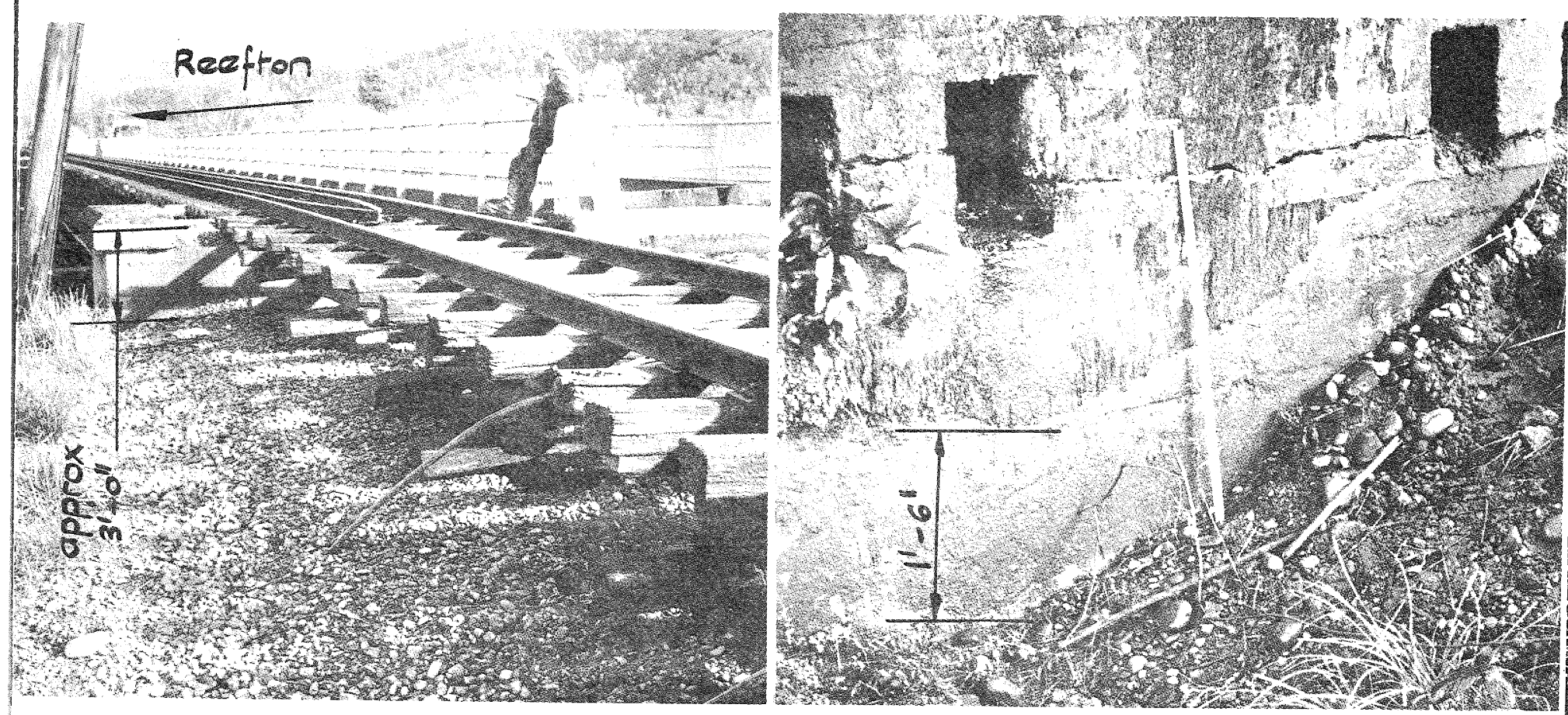

\section{Photo 13.3: Aburment 10} Embankment has settled approximately 3'-0"l

Photo 13.4: Abutment 10. erack through holes for to holding down bolts. ground settlement
Horizontal Note 


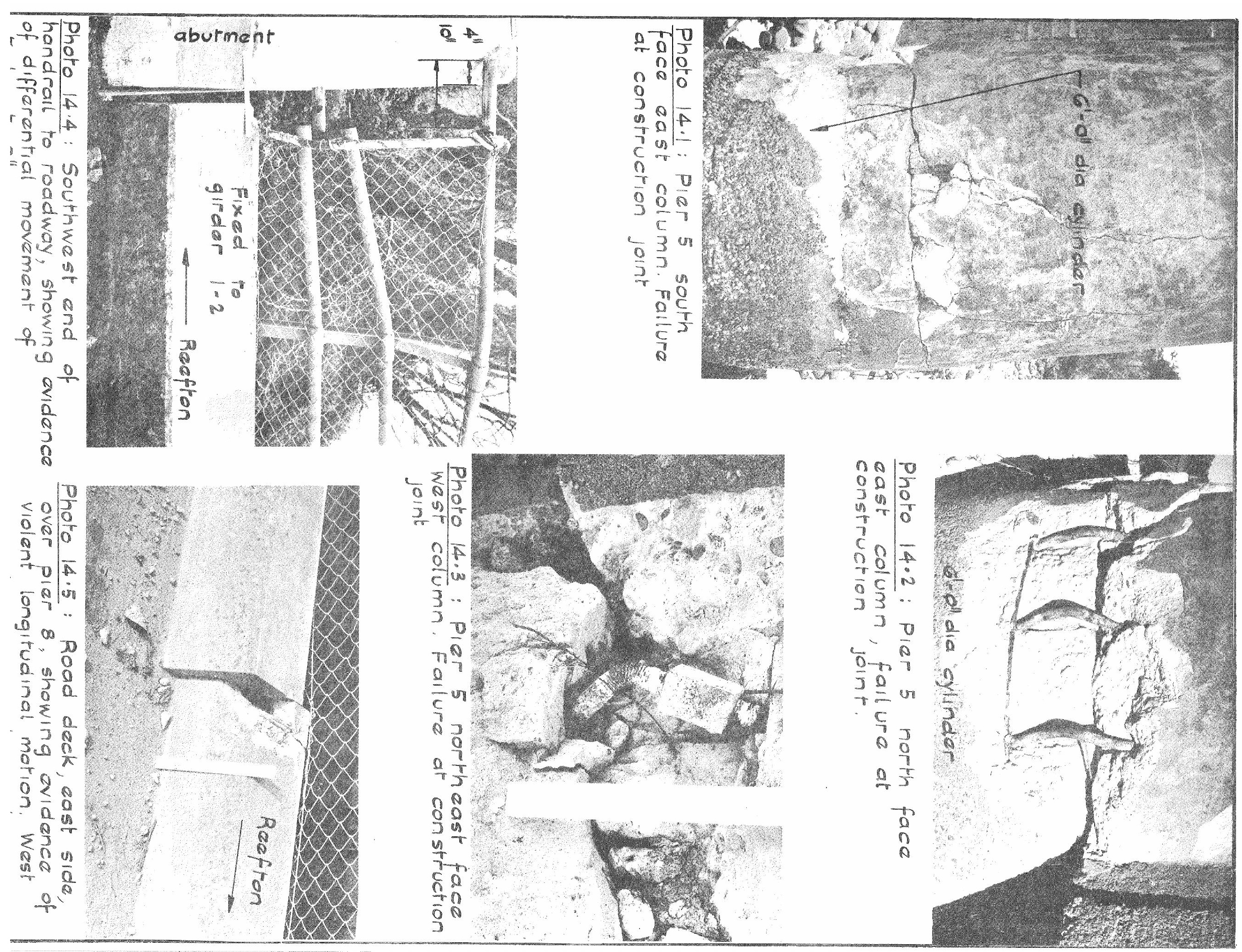




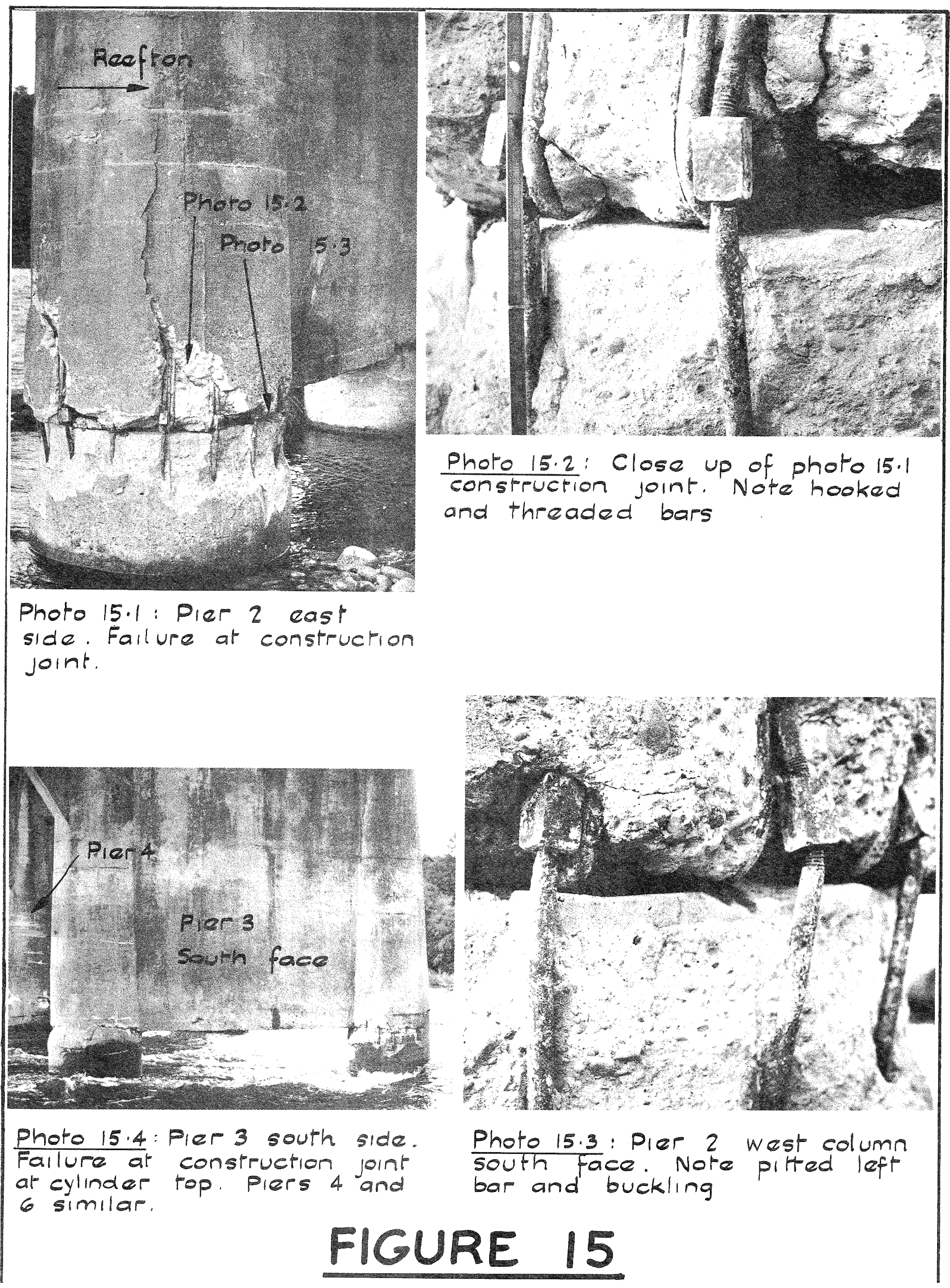

